\title{
1 A global perspective on microbial diversity in the terrestrial
}

2 deep subsurface

3

4 Authors:

\section{Affiliations:}

1. Department of Geography and Earth Sciences (DGES), Aberystwyth University (AU), Wales, UK

2. Institute of Biology, Environmental and Rural Sciences (IBERS), AU

3. Interdisciplinary Centre for Environmental Microbiology (iCEM), AU

4. Department of Biological Sciences, University of Calgary, Canada

5. Institut de Génie Thermique (IGT), Haute École d'Ingénierie et de Gestion du Canton de Vaud (HEIG-VD), Yverdon-les-Bains, Switzerland

6. VTT Technical Research Centre of Finland, Finland

7. Alberta Innovates, Canada

8. University of Toronto, Canada (UT)

9. Center for Biofilm Engineering (CBE), Montana State University (MSU), USA

10. Department of Plant and Microbial Biology, UM, USA

11. Faculty of Biology, Moscow State University (MoSU), Russia

12. Institute of Bioengineering, Research Center of Biotechnology, Russian Academy of Sciences, Russia

13. Department of Earth, Atmospheric and Planetary Sciences (DEAPS), The Massachusetts Institute of Technology (MIT), United States of America (USA)

14. Department of Earth and Planetary Sciences (DEPS), Northwestern University (NWU), USA

15. School of Earth Sciences, The University of Melbourne (UM), Parkville, Australia

16. Department of Microbiology and Immunology at the Peter Doherty Institute for Infection and Immunity, UM

17. Doherty Applied Microbial Genomics, Department of Microbiology and Immunology at the Peter Doherty Institute for Infection and Immunity, UM 
18. Microbiological Diagnostic Unit Public Health Laboratory, Department of Microbiology and Immunology, UM

19. Division of Hydrologic Sciences, Desert Research Institute (DRI), Las Vegas, NV, USA

20. School of Earth and Environmental Sciences (SEES), University of St. Andrews (USA), Scotland, UK

21. Geological Survey of Finland (GTK), Finland

22. Large Lakes Observatory, University of Minnesota - Duluth (UMD)

23. Department of Earth Sciences, UT, Canada 


\section{Summary}

While recent efforts to catalogue Earth's microbial diversity have focused upon surface and marine habitats, $12 \%$ to $20 \%$ of Earth's bacterial and archaeal biomass is suggested to inhabit the terrestrial deep subsurface, compared to $\sim 1.8 \%$ in the deep subseafloor ${ }^{1-3}$. Metagenomic studies of the terrestrial deep subsurface have yielded a trove of divergent and functionally important microbiomes from a range of localities ${ }^{4-6}$. However, a wider perspective of microbial diversity and its relationship to environmental conditions within the terrestrial deep subsurface is still required. Here, we show the diversity of bacterial communities in deep subsurface groundwater is controlled by aquifer lithology globally, by using 16S rRNA gene datasets collected across five countries on two continents and from fifteen rock types over the past decade. Furthermore, our meta-analysis reveals that terrestrial deep subsurface microbiota are dominated by Betaproteobacteria, Gammaproteobacteria and Firmicutes, likely as a function of the diverse metabolic strategies of these taxa. Despite this similarity, evidence was found not only for aquifer-specific microbial communities, but also for a common small consortium of prevalent Betaproteobacteria and Gammaproteobacterial OTUs across the localities. This finding implies a core terrestrial deep subsurface community, irrespective of aquifer lithology, that may play an important role in colonising and sustaining microbial habitats in the deep terrestrial subsurface. An in-silico contamination-aware approach to analysing this dataset underscores the importance of downstream methods for assuring that robust conclusions can be reached from deep subsurface-derived sequencing data. Understanding the global panorama of microbial diversity and ecological dynamics in the deep terrestrial subsurface provides a first step towards understanding the role of microbes in global subsurface element and nutrient cycling.

\section{Main text}

Understanding the distribution of microbial diversity is pivotal for advancing our knowledge of deep subsurface global biogeochemical cycles ${ }^{7,8}$. Subsurface biomass is suggested to have exceeded that of the Earth's surface by an order of magnitude ( $45 \%$ of Earth's total biomass) before land plants evolved, at ca. 0.5 billion years ago ${ }^{9}$. Integrative modelling of cell count and quantitative PCR (qPCR) data and geophysical factors indicated in late 2018 that the bacterial and archaeal biomass found in the global deep subsurface may range from 23 to 31 petagrams of carbon $(\mathrm{PgC})$. These values halved previous efforts from earlier that year ${ }^{10}$ but maintained the notion that the terrestrial deep subsurface holds ca. 5-fold more bacterial and archaeal biomass than the deep marine 
81 subsurface. Further, it is expected that $20-80 \%$ of the possible $2-6 \times 10^{29}$ prokaryotic cells present in 82 the terrestrial subterranean biome exist as biofilms and play crucial roles in global biogeochemical 83 cycles ${ }^{10,11}$.

Cataloguing microbial diversity and functionality in the terrestrial deep subsurface has mostly been achieved by means of marker gene and metagenome sequencing in coals, sandstones, carbonates, and clays, as well as deep igneous and metamorphic rocks ${ }^{4-6,12-20}$. Only recently has the first comprehensive database of $16 \mathrm{~S}$ rRNA gene-based studies targeting terrestrial subsurface environments been compiled ${ }^{10}$. This work focused on updating estimates for bacterial and archaeal biomass, and cell numbers across the terrestrial deep subsurface, but also linked the identified bacterial and archaeal phylum-level compositions to host-rock type, and to 16S rRNA gene region primer targets ${ }^{10}$. While highlighting Firmicutes and Proteobacterial dominance in the bacterial component of terrestrial deep subsurface, no further taxonomic insights were gained. However, genus-level identification is critical for understanding community composition, inferred metabolism and hence microbial contributions of distinct community members to biogeochemical cycling in the deep subsurface ${ }^{18,21-23}$. Indeed, such genus-specific traits have been demonstrated as critical for understanding crucial biological functions in other microbiomes ${ }^{24}$, and genus-specific functions of relevance for deep subsurface biogeochemistry are clear ${ }^{25,26}$.

So far, the potential biogeochemical impacts of microbial activity in the deep subsurface have been inferred through shotgun metagenomics, as well as from incubation experiments of primary geological samples amended with molecules or minerals of interest ${ }^{13,19,20,27-30}$. Recent studies of deep terrestrial subsurface microbial communities further suggest that these are metabolically active, generally associated with novel uncultured phyla, and potentially directly involved in carbon and sulphur cycling ${ }^{31-36}$. Concomitant advancements in subsurface drilling, molecular methods and computational techniques have aided the exploration of the subsurface biosphere, but serious challenges remain mostly related to deciphering sample contamination by drilling methods and sample transportation to laboratories for processing ${ }^{37,38}$. The logistical challenges inherent to accessing and recovering in situ samples from hundreds to thousands of metres below surface complicate our view of terrestrial subsurface microbial ecology ${ }^{39}$.

In this study, we capitalize on the increased availability of 16S rRNA gene amplicon data from

113 multiple studies of the terrestrial deep subsurface conducted over the last decade. We apply bespoke 114 bioinformatic scripts to generate insights into the microbial community structure and controls upon 115 bacterial microbiomes of the terrestrial deep subsurface across a large distribution of habitat types on 
116 multiple continents. The deep biosphere is as-yet undefined as a biome - elevated temperature, anoxic

117 conditions, low levels of organic carbon, and measures of isolation from the surface photosphere are 118 some of the criteria used albeit without a consensus. For this work a more general approach has been 119 taken to define the terrestrial deep subsurface as the zone at least $100 \mathrm{~m}$ from the surface ${ }^{40,41}$.

\section{Meta-analysis of the terrestrial deep subsurface microbiome}

122 Here, we were able to compare datasets encompassing different 16S rRNA gene hyper-variable 123 regions, and derived from different DNA extraction methodologies, facilitated by closed-reference 124 Operational Taxonomic Unit (OTU)-picking of each study individually using the same 16S rRNA 125 gene reference database. This procedure begins to address technically confounding variables by 126 limiting taxonomy assignments to only the archaeal and bacterial diversity listed in the chosen 127 database and precludes the discovery of novel taxa.

129 The finalized meta-analysis dataset comprised of 16S rRNA data from seventeen aquifers in either 130 sedimentary- or crystalline-host rocks, from depths spanning $94 \mathrm{~m}$ to $2300 \mathrm{~m}$ below land surface 131 (mbls), targeting mostly groundwater across 5 countries and two continents (Supplementary Table 132 3). Nine DNA extraction techniques were used in these studies, ranging from standard and modified 133 kit protocols (e.g. MOBIO ${ }^{\circledR}$ PowerSoil, see Table 1) to phenol-chloroform and CTAB/NaCl based 134 methods ${ }^{42-47}$. Finally, 6 different primer pair amplified regions of the 16S rRNA gene, in 454 135 pyrosequencing and Illumina sequencing, were used to generate the datasets. 
137 Table 1. Metadata table for the studies utilized in this meta-analysis ( $c f$. Supplementary Table 3 and Supplementary Figure 3 for more details). NA

138 is used as an acronym for "not available". The dataset unavailable through SRA is available through http://hmp.ucalgary.ca/HMP/.

139




142 Initial processing of 187 retrieved samples revealed 24,632,035 chimera-checked sequences 17,28,43,44,48-50. SILVA 123-aided closed-reference OTU-picking yielded 6,975 OTUs associated to 144598,341 sequences following exclusion of singleton OTUs and samples containing 2 or less OTUs. 145 The final dataset following stricter contamination-aware filtering ( $c f$. Methodology) was comprised 146 of 70 samples and 2,207 OTUs (513,929 sequences, $2.54 \%$ of the initial sequences), where Archaeal 147 reads comprised $1.5 \%$ of the total number of reads.

\section{Trends in taxonomic diversity}

150 Among a total of 45 detected bacterial phyla, Proteobacteria were seen to dominate most community 151 profiles in this dataset (Figure 1). The most abundant proteobacterial classes (Alpha-, 152 Betaproteobacteria, Delta-, Gammaproteobacteria) represented 57.2\% of the total number of reads, 153 with $13.4 \%$ of these assigned to class Clostridia (Firmicutes). A general prevalence of 154 Betaproteobacteria and Gammaproteobacteria in the deep biosphere may be explained by the diverse metabolic capabilities of taxa within these clades. Families Gallionellaceae, Pseudomonadaceae,

156 Rhodocyclaceae and Hydrogeniphillaceae within Betaproteobacteria and Gammaproteobacteria are 157 suggested to play crucial roles in deep subsurface iron, nitrogen, sulphur and carbon cycling across 158 the world ${ }^{43,51,52}$. The relative abundance of order Burkholderiales (Betaproteobacteria) in surficial 159 soils has previously been correlated $\left(\mathrm{R}^{2}=0.92\right.$, ANOVA p-value $\left.<0.005\right)$ with mineral dissolution 160 rates, while genus Pseudomonas (Gammaproteobacteria) is widely known to playing a key role in hydrocarbon-degradation, denitrification and coal solubilisation in different locations ${ }^{53-55}$.

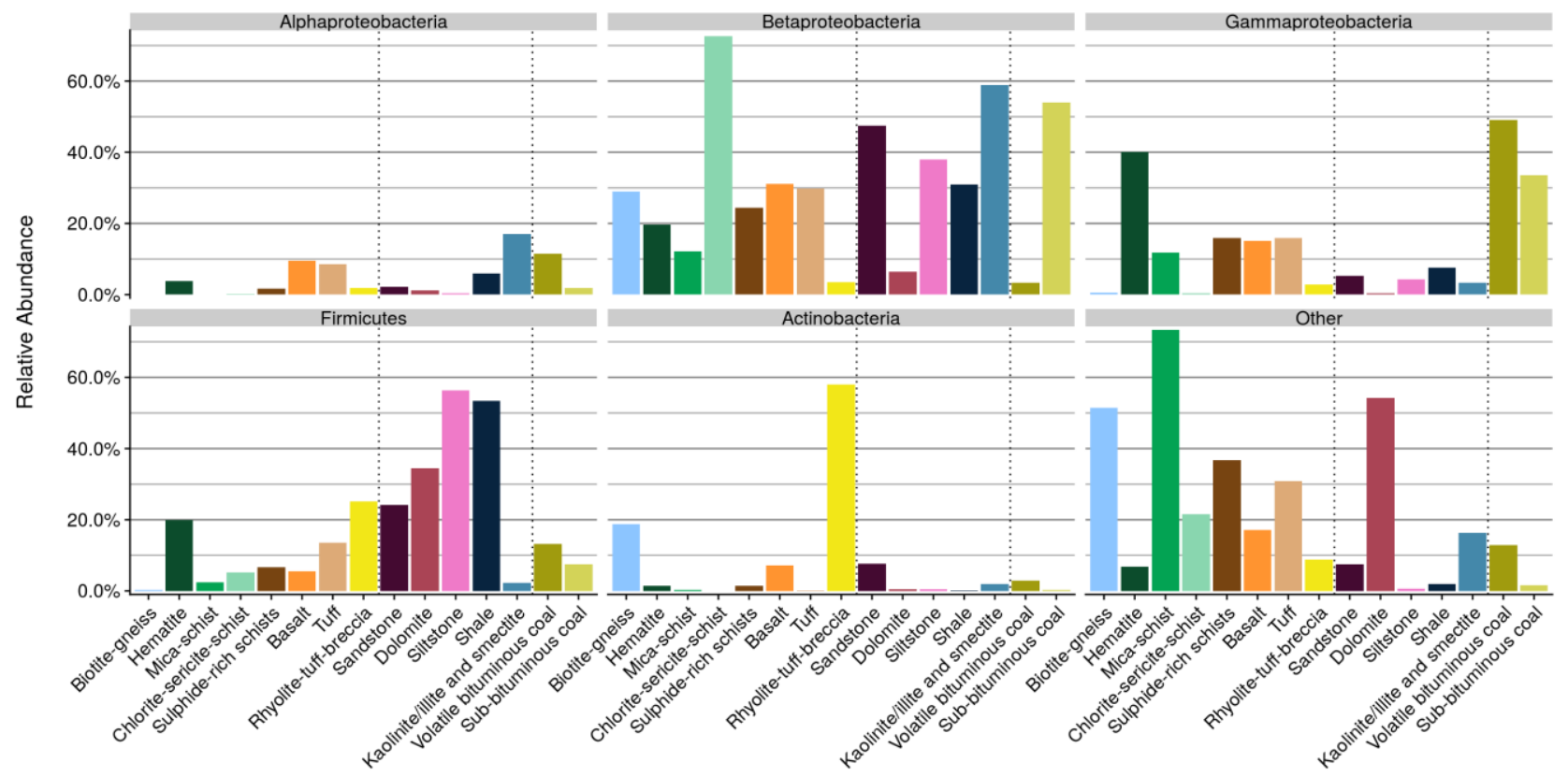

Figure 1. Mean relative abundances (\%, y-axis) of the most abundant taxonomic groups across the dataset across all analysed aquifer lithologies (x-axis). Vertical dashed lines divide crystalline and 
sedimentary rocks. Coals ranks are also separated due to their higher sample contribution to the dataset.

Mean grouped proportion values indicated that Betaproteobacteria were the most abundant proteobacterial class in most host rocks, representing $26.1 \%$ of all reads in the dataset. While Betaproteobacteria accounted for $53.96 \%$ of the community profile for sub-bituminous coals, Gammaproteobacteria dominated volatile bituminous coals $(49.1 \%$ of the profile, Figure 1). The dominance of Betaproteobacteria and Gammaproteobacteria in coals builds on culture-based evidence of widespread degradation of coal-associated complex organic compounds by these classes 56-59

Firmicutes were represented in large part by class Clostridia and mostly associated with sedimentary aquifers (i.e. sandstone, dolomite, siltstone, shale - Figure 1). This class includes ubiquitous anaerobic hydrogen-driven sulphate reducers also known to sporulate and metabolize a wide range of organic carbon compounds that have been found to dominate extremely deep subsurface ecosystems beneath South Africa and likely globally given the pervasive high levels of $\mathrm{H}_{2}$ in similar geologic settings ${ }^{13,60-62}$. Clostridia from metagenomes have been detected from the terrestrial deep subsurface and inferred to have the physiological capabilities needed to thrive in these environments 20. Adaptation to extreme environments in Clostridia is posed to be driven by varied metabolic potential, sporulation ability, and capacity for $\mathrm{CO}_{2}$ - or sulphur-based autotrophic $\mathrm{H}_{2}$-dependent growth 22,63 .

\section{Lithological controls on community structure}

Microbial community structure and composition in soils depend on fine-tuned geochemical, physical and hydrogeological conditions that influence microbial presence and metabolism ${ }^{64}$. This relationship also appears to be reflected in the global subsurface, where host-rock lithology is evident as a primary control on community structure (Figures 2 and 3). Indeed, most host-rocks (10 out of 15 in this dataset) have, on average, more unique OTUs than they share with other host-rocks (Figure 2). Particularly, in sulphide-rich schists, $73 \%$ of the OTUs are, on average, unique to the host-rock. The role of host-rock lithology is further evidenced (Figure 3) as some of the host-rocks clustered at a 95\% confidence interval, suggesting closely related microbial communities within similar lithologies, despite other environmental factors such as depth or location. Further, 50.6\% of JensenShannon distances ordinated (Figure 3) were significantly explained by aquifer lithology (ADONIS/PERMANOVA, F-statistic=4.65, p-value <0.001, adjusted Bonferroni correction p-value $<0.001$ ); thus showing that rock type was the primary variable defining microbial community 
structure. Other environmental features such as absolute sample depth and medium-scale location

201 (i.e. state, region of the sampling site) explained only $3.08 \%$ and $2.78 \%$ of the significant metadatadriven variance in microbial community structure, respectively (ADONIS/PERMANOVA, Fstatistic $=3.95,3.57$ p-value $<0.001$, adjusted Bonferroni correction p-value $<0.001)$. This suggests that depth-related changes in temperature and pressure are not significant controls on community structure. The relationship of community structure to hydrogeochemical parameters remains an area for future investigation - since hydrogeology and fluid geochemistry are also strongly controlled by lithology via water-rock reactions.

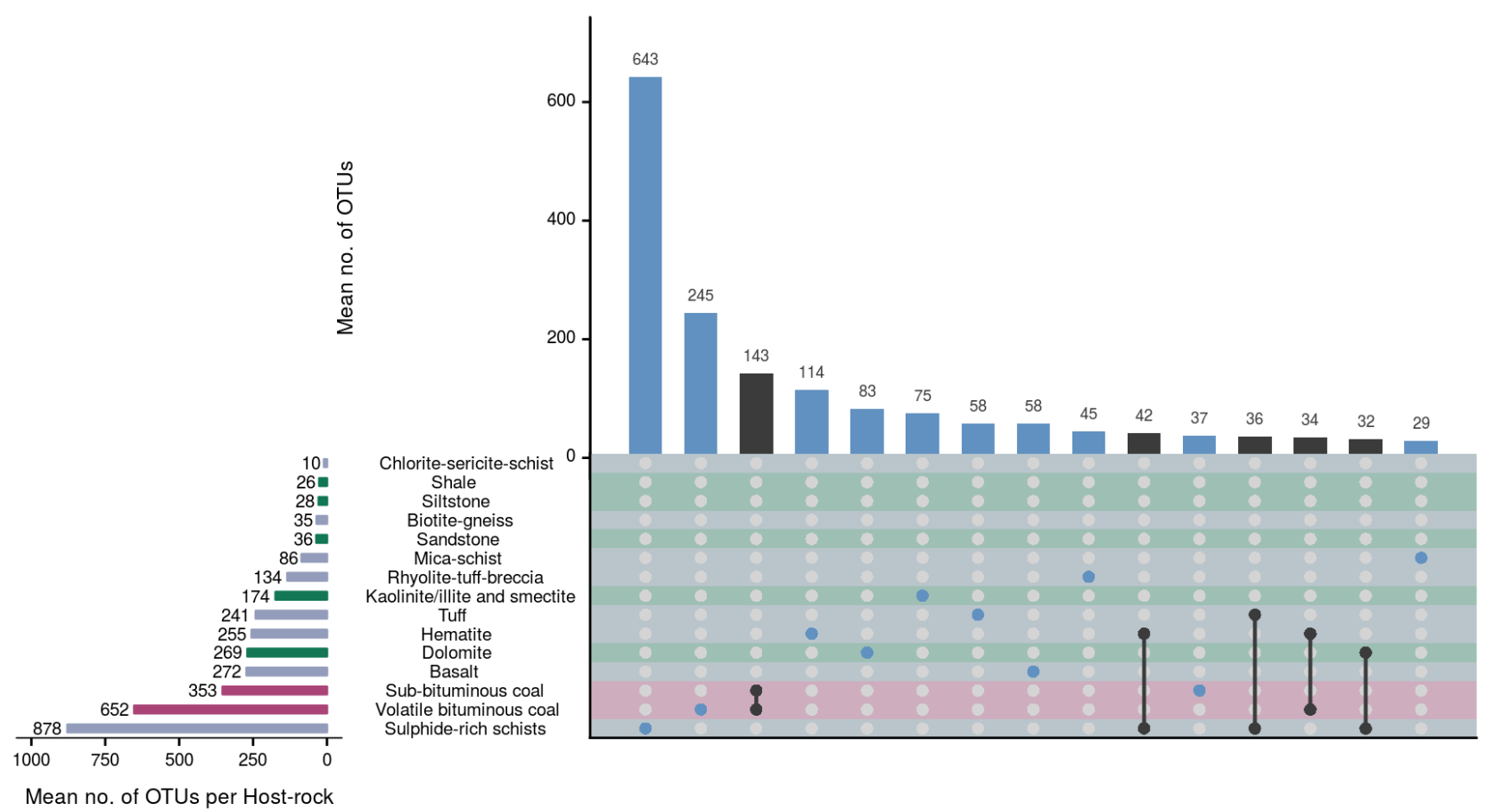

Figure 2. UpsetR plot of mean numbers of OTU interactions among rock types. Only interactions involving 25 or more OTUs on average are shown. Coloured matrix rows correspond to host-rocks, and are coloured according to rock type: blue for crystalline, green for sedimentary rocks and pink

212 for coals, which were highlighted due to their higher sample contribution to the dataset. Columns 213 depict OTU interactions: blue dots mark independent (mean number of non-shared OTUs) 214 interactions and black dots connected by black lines mark shared OTUs between two or more host215 rocks. Shared interactions are composed of only the host-rocks marked by dots. Vertical bars on top 216 of the coloured matrix correspond to mean OTU numbers present in the described interactions and 217 are coloured black or blue if depicting shared or non-shared interactions, respectively. Horizontal bars by the left of the coloured matrix depict mean total numbers of OTUs per host-rock. 
A

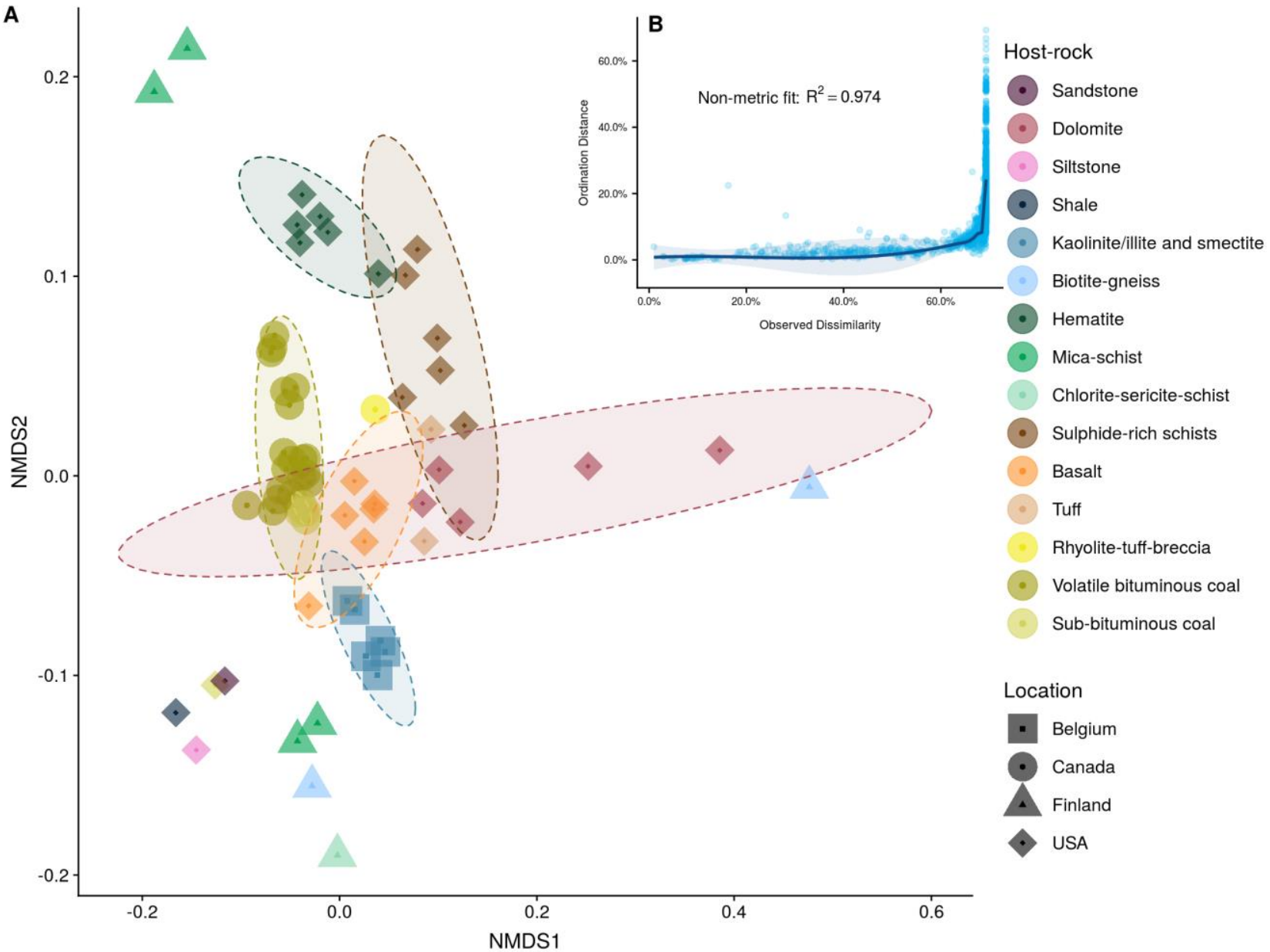

Figure 3. Non-metric Multidimensional Scaling (nMDS) of Jensen-Shannon distances between samples (A). Shapes correspond to different locations, whereas colours depict host-rocks targeted in this study. B depicts a Shepard's stress plot of observed (original) dissimilarities and ordination distances. An $\mathrm{R}^{2}$ measure of stress is further shown for the non-metric fit of the variables. Confidence interval ellipses were plotted at a level of $95 \%$ according to host-rock.

Metadata variables that were unavailable for all samples in the dataset were excluded from the statistical analyses, thus further insights into the significance of other environmental variables was not possible. Nevertheless, this is the first large-scale evidence that deep subsurface microbial community taxonomy appears host-rock-specific. Given the importance of chemolithotrophic metabolisms in dark, subsurface environments, the unique chemical and mineralogical compositions within different aquifer lithologies impart strong controls over microbiomes associated with mineral surfaces and porewaters ${ }^{43,62,65-67}$. Indeed, direct utilisation of mineral surfaces or dissolved species from minerals for respiration and/or metabolism has been shown to be critical in localised subsurface environments ${ }^{30,35,68,69}$. Due to low numbers of samples for some host-rock lithologies in this dataset (e.g. one sample each for siltstone, sandstone, shale and chlorite-sericite-schist), it is not possible to ascertain that microbiome specificity is generalisable to all deep subsurface aquifer types on Earth 
237 (see Figure 3). Nevertheless, this study provides the first large-scale evidence that, at a global scale, 238 lithology surpasses depth in shaping deep subterranean microbial communities.

A core terrestrial deep subsurface microbial community?

241 Analysis of prevalence across the dataset revealed that seven OTUs, all affiliated to genus 242 Pseudomonas, were present in more than 25 and up to 41 samples (see Supplementary Figure 1, 243 Supplementary Table 2). Network analysis (Table 2) highlighted a Pseudomonas OTU highly 244 connected to other OTUs in the dataset. Further, BLAST ${ }^{70}$ results indicated that recovered sequences 245 for OTUs affiliated to this genus were generally associated to marine and terrestrial soil and sediments 246 ( $c f$ Supplementary Table 4, Supplementary Figure 4). Four OTUs affiliated to Burkholderiales 247 (Betaproteobacteria), the second most prevalent order in the dataset, were also found to be connected 248 to up to 34 other OTUs. Genus Thauera (Betaproteobacteria, Rhodocyclales), represented by a single 249 OTU, was the second most central to the dataset. Finally, network and prevalence analysis highlighted 250 the putative importance classes Betaproteobacteria and Gammaproteobacteria may have in the deep 251 subsurface, since taxa affiliated to these were highly connected across the dataset (Table 2). These 252 observations suggest genus-level taxonomy may be relevant to shaping subterranean microbial 253 communities irrespective of host-rock lithology. 
255 Table 2. Top 10 most central OTUs in the Jaccard distances network (as defined by eigenvector centrality scores, or the scored value of the centrality of 256 each connected neighbour of an OTU) and correspondent closeness centrality (scores of shortest paths to and from an OTU to all the remainder in a 257 network) and degree (number of directly connected edges, or OTUs) values.
OTU ID
OTU Classification

\begin{tabular}{|c|c|c|c|c|}
\hline EF554871.1.1486 & Proteobacteria; Gammaproteobacteria; Pseudomonadales; Pseudomonadaceae; Pseudomonas & 1.0000000 & $2.13 \mathrm{e}-05$ & 38 \\
\hline НH792638.1.1492 & Proteobacteria; Betaproteobacteria; Rhodocyclales; Rhodocyclaceae; Thauera & 0.9753542 & $2.13 \mathrm{e}-05$ & 36 \\
\hline HQ681977.1.1496 & Proteobacteria; Betaproteobacteria; Burkholderiales; Comamonadaceae; Diaphorobacter & 0.9445053 & $2.13 \mathrm{e}-05$ & 34 \\
\hline KF465077.1.1336 & Proteobacteria; Betaproteobacteria; Burkholderiales; Comamonadaceae; Acidovorax & 0.8887751 & $2.13 e-05$ & 30 \\
\hline JQ072853.1.1348 & Proteobacteria; Betaproteobacteria; Rhodocyclales; Rhodocyclaceae; Thauera & 0.8808435 & $2.13 \mathrm{e}-05$ & 30 \\
\hline KM200734.1.1449 & Proteobacteria; Alphaproteobacteria; Rhizobiales; Rhizobiaceae; Rhizobium & 0.8716886 & $2.13 \mathrm{e}-05$ & 31 \\
\hline KC758926.1.1392 & Proteobacteria; Betaproteobacteria; Burkholderiales; Comamonadaceae; Acidovorax & 0.8662805 & $2.13 e-05$ & 29 \\
\hline FJ032194.1.1456 & Proteobacteria; Betaproteobacteria; Burkholderiales; Comamonadaceae; Rhodoferax & 0.8662805 & $2.13 \mathrm{e}-05$ & 29 \\
\hline EU771645.1.1366 & Firmicutes; Bacilli; Bacillales; Planococcaceae; Planomicrobium & 0.8476970 & $2.13 e-05$ & 30 \\
\hline JN245782.1.1433 & Proteobacteria; Alphaproteobacteria.; Rhodobacterales; Rhodobacteraceae; Defluviimonas & 0.8356655 & $2.13 \mathrm{e}-05$ & 29 \\
\hline
\end{tabular}


259 The metabolic plasticity of Pseudomonadales and Burkholderiales orders has been demonstrated ${ }^{71-}$

$260{ }^{74}$ and may be a catalyst for their apparent centrality across the terrestrial deep subsurface 261 microbiomes analysed in this study. These bacterial orders may represent important keystone taxa in 262 microbial consortia responsible for providing key substrates to other colonizers in deep subsurface 263 environments ${ }^{75,76}$. In particular, given the number of highly central Pseudomonas-affiliated OTUs 264 and the prevalence of this genus in the dataset, we suggest that this genus may be key in establishing 265 conditions for microbial colonization in many terrestrial subsurface environments. Genus 266 Pseudomonas and possibly several members of Burkholderiales may therefore comprise an important 267 component of the global core terrestrial deep subsurface microbial community.

\section{Challenges from contamination}

270 16S rRNA gene PCR-based approaches for characterizing microbial diversity in low biomass 271 environments benefit from the sensitivity afforded by PCR, at the cost of vulnerability to 272 contamination ${ }^{77}$. Here, we used the prominence of sequences associated with phototrophic taxa as 273 an indicator of either ingress of surface microbiota or contamination during sample processing. The discovery of potentially photosynthetic taxa in the initial dataset, namely 46 OTUs classified as Chloroplast (Cyanobacteria) was read as a sign that further bioinformatics-driven precautions should be taken, despite recent evidence of some cyanobacterial presence in some locations within the deep subsurface ${ }^{78,79}$. Specifically, the presence of other phototrophic members of phyla Chloroflexi and Chlorobi as well as classes Rhodospirillales (Alphaproteobacteria) and Chromatiales (Gammaproteobacteria) informed the decision to filter the dataset to hold only OTUs represented by more than 500 sequences and present in at least 10 samples. Recent recommendations for quality control of 16S rRNA gene datasets also support filtering-based approaches when applied to low biomass subsurface environments ${ }^{38}$. This constraint reduced the dataset to the 70 samples and 2,207 OTUs (513,929 sequences) used for the meta-analysis (Table 1), and also reduced the number of prospective contaminants by half, although only $\sim 26 \%$ of the reads associated to Chloroplast-like sequences were removed (17 OTUs, 1958 reads).

287 Collecting contamination-free samples from the deep subsurface is difficult but important for cataloguing the authentic microbial diversity of the terrestrial subsurface. This study follows recent recommendations for downstream processing of contaminant-prone samples originated in the deep subsurface (Census of Deep Life project - http://codl.coas.oregonstate.edu/), where physical, chemical and biological, but also in-silico bioinformatics strategies to prevent erroneous conclusions have been highlighted ${ }^{38,80,81}$. This study also follows frequency-based OTU filtration techniques 
293 similar to those recommended in Sheik et al. (2018) ${ }^{38}$ and designed to remove possible contaminants 294 introduced during sampling or during the various steps related to sample processing. The pre-emptive quality control steps hereby undertaken support a non-contaminant origin for taxa analysed in this dataset following careful in-field and laboratorial contamination-aware procedures carried out in each study. As such, the predominance of typically contaminant taxa affiliated e.g. to genus Pseudomonas was accepted as a true trend in the microbial ecology of the terrestrial deep subsurface.

No evidence was found for DNA extraction and PCR procedures significantly affecting microbial community structure in this meta-analysis $(6.01 \%$ of the microbial community structure cumulatively [ADONIS/PERMANOVA, F-statistic=3.85, 3.23, p-value $<0.01$, adjusted Bonferroni correction pvalue $<0.001]$ vs. $50.6 \%$ from host rock lithology). In spite of this, a general convergence in DNA extraction methods would help further reduce methodology based variation and to standardize downstream analysis of deep subsurface microbial datasets ${ }^{82}$, despite the practical challenges of each host-rock matrix and local geochemical conditions.

In the near future, the advent of recently developed techniques for primer bias-free long read 16S rRNA and 16S rRNA-ITS gene amplicon long-read-based sequencing may initiate a convergence of molecular methods from which the deep subsurface microbiology community would benefit greatly ${ }^{83,84}$. The future of large-scale, collaborative deep subsurface microbial diversity studies should encompass not only an effort towards standardization of several molecular biology techniques but also the long-term archival of samples ${ }^{85}$. This will permit re-analyses using updated or unified methods after collection, where methodological variations would be controlled, and robust conclusions would more easily be achieved.

A global scale meta-analysis addressing the available 16S rRNA gene-based studies of the deep terrestrial subsurface revealed the dominance of Betaproteobacteria, Gammaproteobacteria and Firmicutes across this biome. Further, aquifer lithology was identified as the main driver of deep subterranean microbial communities. Depth and location were not significant controls of microbial community structure at this scale. Finally, evidence for a core terrestrial deep subsurface microbiome population was recognised through the prevalence and centrality of genus Pseudomonas (Gammaproteobacteria) and several other genera affiliated to class Betaproteobacteria. The adaptable metabolic capabilities associated to the above-mentioned taxa may be critical for colonizing the deep subsurface and sustaining communities. The terrestrial deep subsurface is a hard-to-reach complex 
ecosystem crucial to global biogeochemical cycles. This study attempts to consolidate a global-scale understanding of taxonomical trends underpinning terrestrial deep subsurface microbial ecology and geomicrobiology.

\section{Methodology}

\section{Data acquisition}

332 The Sequence Read Archive database of the National Center for Biotechnology Information (SRA333 NCBI) was queried for 16S rRNA-based deep subsurface datasets (excluding marine and ice samples, 334 as well as any human-impacted samples); available studies, were downloaded using the SRA Run 335 Selector. Studies were selected considering the metadata and information on sequencing platform 336 used - i.e., only samples derived from 454 pyrosequencing and Illumina sequencing were considered. 337 Analysis of related literature resulted in the detection of other deposited studies previous search 338 efforts in NCBI-SRA failed to detect. Further private contacts allowed access to unpublished data 339 included in this study. The final list of NCBI accession numbers, totalling 222 samples, was downloaded using fastq-dump from the SRA toolkit

\section{1 (https://www.ncbi.nlm.nih.gov/sra/docs/toolkitsoft/).}

342 As seen in Table 1, required metadata included host-rock lithology, general and specific geographical 343 locations, depth of sampling, DNA extraction method, sequenced 16S rRNA gene region and 344 sequencing method. Any samples for which the above-mentioned metadata could not be found were 345 discarded and not considered for downstream analyses.

\section{Pre-processing of 16S rRNA gene datasets}

347 A customised pipeline was created in bash language making use of python scripts developed for 348 QIIME v1.9.1 ${ }^{86}$, to facilitate bioinformatic analyses in this study (see 349 https://github.com/GeoMicroSoares/mads_scripts for scripts). Briefly, demultiplexed FASTQ files 350 were processed to create an OTU table. Quality control steps involved trimming, quality-filtering and 351 chimera checking by means of USEARCH $6.1^{87}$. Sequence data that passed quality control were then 352 subjected to closed-reference (CR) OTU-picking on a per-study basis using UCLUST ${ }^{87}$ and reverse 353 strand matching against the SILVA v123 taxonomic references (https://www.arb354 silva.de/documentation/release-123/). Closed-reference OTU picking excludes OTUs whose 355 taxonomy has not been found in the 16S rRNA gene database used. Although this limits the recovery 356 of prokaryotic diversity to the recorded in the database, cross-study comparisons of microbial communities generated by different $16 \mathrm{~S}$ rRNA gene primers are made possible. This conservative 
approach classified OTUs in each study individually to the common 16S rRNA gene reference database the merge of all classification outputs. A single BIOM (Biological Observation Matrix) file was generated using QIIME's merge_otu_tables.py script. The BIOM file was then filtered to exclude samples represented by less than 2 OTUs using filter_samples_from_otu_table.py, as well as OTUs represented by one sequence (singleton OTUs) by using filter_otus_from_otu_table.py. In an attempt to reduce the impacts of potential contaminant OTUs from the dataset, the post-singleton filtered dataset was further filtered to include only OTUs represented by at least 500 sequences and present in at least 10 samples overall using filter_otus_from_otu_table.py.

\section{Data analysis}

All downstream analyses were conducted using the phyloseq (https://github.com/joey711/phyloseq) package within $\mathrm{R}$, which allowed for simple handling of metadata and taxonomy and abundance data ${ }^{88-90}$. Merged and filtered BIOM files were imported into R using internal phyloseq functions, which allowed further filtering, transformation and plotting of the dataset (see https://github.com/GeoMicroSoares/mads_scripts for scripts).

Briefly, following a general assessment of the number of reads across samples and OTUs, tax_glom (phyloseq) allowed the agglomeration of the OTU table at phylum-level. For the metadata categorydirected analyses, function merge_samples (phyloseq) created averaged OTU tables, which permitted testing of hypotheses for whether geology or depth had significant impacts on microbial community structure and composition. Computation of a Jensen-Shannon divergence PCoA (Principal 378 Coordinate Analysis) was achieved with ordinate (phyloseq) which makes use of metaMDS (vegan) 91,92. All figures were plotted making use of the ggplot2 $\mathrm{R}$ package

380 (https://github.com/tidyverse/ggplot2), except for the UpsetR plot in Figure 2, which was plotted with package UpsetR (https://github.com/hms-dbmi/UpSetR). 


\section{References}

384 1. McMahon, S. \& Parnell, J. Weighing the deep continental biosphere. FEMS Microbiol. Ecol. 87, 113-120 (2014).

2. Bar-On, Y. M., Phillips, R., Milo, R. \& Falkowski, P. G. The biomass distribution on Earth. PNAS (2018). doi:10.1073/pnas.1711842115

3. Thompson, L. R. et al. A communal catalogue reveals Earth's multiscale microbial diversity. Nature 551, 457-463 (2017).

4. $\quad$ Long, P. E., Williams, K. H., Hubbard, S. S. \& Ban, J. F. Microbial Metagenomics Reveals Climate-Relevant Subsurface Biogeochemical Processes. Trends Microbiol. 24, 1-11 (2016).

5. Anantharaman, K. et al. Thousands of microbial genomes shed light on interconnected biogeochemical processes in an aquifer system. Nat. Commun. 7, 1-11 (2016).

6. Hug, L. A. et al. Critical biogeochemical functions in the subsurface are associated with bacteria from new phyla and little studied lineages. Environ. Microbiol. 18, 159-173 (2016).

7. Jelen, B. I., Giovannelli, D. \& Falkowski, P. G. The Role of Microbial Electron Transfer in the Coevolution of the Biosphere and Geosphere. 45-62 (2016). doi:10.1146/annurev-micro102215-095521

8. Falkowski, P. G., Fenchel, T. \& Delong, E. F. The Microbial Engines That Drive Earth's Biogeochemical Cycles. Science (80-. ). 320, 1034-1039 (2008).

9. McMahon, S. \& Parnell, J. The Deep History of Earth's Biomass. J. Geol. Soc. London. jgs2018-061 (2018). doi:10.1144/jgs2018-061

10. Magnabosco, C. et al. The biomass and biodiversity of the continental subsurface. Nat. Geosci. 1 (2018). doi:10.1038/s41561-018-0221-6

14. Miettinen, H. et al. Microbiome composition and geochemical characteristics of deep subsurface high-pressure environment, Pyhäsalmi mine Finland. Front. Microbiol. 6, 1-16 (2015).

11. Flemming, H.-C. \& Wuertz, S. Bacteria and archaea on Earth and their abundance in biofilms. Nat. Rev. Microbiol. 1 (2019). doi:10.1038/s41579-019-0158-9

12. Gihring, T. M. et al. The distribution of microbial taxa in the subsurface water of the kalahari shield, south africa. Geomicrobiol. J. 23, 415-430 (2006).

13. Moser, D. P. et al. Desulfotomaculum spp. and Methanobacterium spp. Dominate 4-5 km Deep Fault. Appl. Environ. Microbiol. 71, 8773-8783 (2005).

15. Bagnoud, A. et al. Reconstructing a hydrogen-driven microbial metabolic network in Opalinus Clay rock. Nat. Commun. 7, 12770 (2016). 
deep subsurface Cambrian Sandstone reservoir. Environ. Microbiol. 16, 1695-708 (2014).

17. Purkamo, L., Bomberg, M., Kietäväinen, R., Salavirta, H. \& Nyyssönen, M. Microbial cooccurrence patterns in deep Precambrian bedrock fracture fluids. Biogeosciences 3091-3108 (2016). doi:10.5194/bg-13-3091-2016

18. Purkamo, L. et al. Diversity and functionality of archaeal, bacterial and fungal communities in deep Archaean bedrock groundwater. FEMS Microbiol. Ecol. (2018). doi:10.1093/femsec/fiy116

19. Baker, B. J. et al. Related assemblages of sulphate-reducing bacteria associated with ultradeep gold mines of South Africa and deep basalt aquifers of Washington State. Environ. Microbiol. 5, 267-277 (2003).

20. Chivian, D. et al. Environmental Genomics Reveals a Single-Species Ecosystem Deep Within Earth. Science (80-. ). 322, 275-278 (2008).

21. Ueno, A., Shimizu, S., Tamamura, S., Okuyama, H. \& Naganuma, T. Anaerobic decomposition of humic substances by Clostridium from the deep subsurface. Nat. Publ. Gr. 1-9 (2016). doi:10.1038/srep18990

28. Wouters, K., Moors, H., Boven, P. \& Leys, N. Evidence and characteristics of a diverse and metabolically active microbial community in deep subsurface clay borehole water. FEMS Microbiol. Ecol. 86, 458-473 (2013).

29. Ünal, B. et al. Trace elements affect methanogenic activity and diversity in enrichments from subsurface coal bed produced water. Front. Microbiol. 3, 1-14 (2012). 
30. Hernsdorf, A. W. et al. Potential for microbial $\mathrm{H} 2$ and metal transformations associated with novel bacteria and archaea in deep terrestrial subsurface sediments. ISME J. 11, 1915-1929 (2017).

31. Lopez-Fernandez, M. et al. Investigation of viable taxa in the deep terrestrial biosphere suggests high rates of nutrient recycling. FEMS Microbiol. Ecol. 94, (2018).

32. Lloyd, K. G., Ladau, J., Steen, A. D., Yin, J. \& Crosby, L. Phylogenetically novel uncultured microbial cells dominate Earth microbiomes. bioRxiv 303602 (2018). doi:10.1101/303602

33. Lollar, B. S. et al. Unravelling abiogenic and biogenic sources of methane in the Earth's deep subsurface. Chem. Geol. 226, 328-339 (2006).

34. Lin, L. et al. Long-Term Sustainability of a High-Energy, Low-Diversity Crustal Biome. Science (80-. ). 314, (2006).

35. Li, L. et al. Sulfur mass-independent fractionation in subsurface fracture waters indicates a long-standing sulfur cycle in Precambrian rocks. Nat. Commun. 7, 13252 (2016).

36. Lollar, G. S., Warr, O., Telling, J., Osburn, M. R. \& Sherwood Lollar, B. "Follow the Water": Hydrogeochemical Constraints on Microbial Investigations $2.4 \mathrm{~km}$ below surface at the Kidd Creek Deep Fluid and Deep Life Observatory. Geomicrobiol. J. In review, (2019).

37. Griffin, W. T., Phelps, T. J., Colwell, F. S. \& Fredrickson, J. K. in Microbiology of the Terrestrial Deep Subsurface 23-44 (CRC Press, 2018). doi:10.1201/9781351074568-3

38. Sheik, C. S. et al. Identification and removal of contaminant sequences from ribosomal gene databases: Lessons from the Census of Deep Life. Front. Microbiol. 9, 840 (2018).

39. Wilkins, M. J. et al. Trends and future challenges in sampling the deep terrestrial biosphere. Front. Microbiol. 5, 1-8 (2014).

40. Brockman, F. J., Murray, C. J. \& Murray, C. J. in The Microbiology of the Terrestrial Deep Subsurface 75-102 (CRC Press, 2018). doi:10.1201/9781351074568-6

41. Russell, B. F., Phelps, T. J., Griffin, W. T. \& Sargent, K. A. Procedures for Sampling Deep Subsurface Microbial Communities in Unconsolidated Sediments. Groundw. Monit. Remediat. 12, 96-104 (1992).

42. Andreou, L. V. in Methods in Enzymology 529, 143-151 (John Wiley \& Sons, Inc., 2013).

43. Osburn, M. R., LaRowe, D. E., Momper, L. M. \& Amend, J. P. Chemolithotrophy in the continental deep subsurface: Sanford Underground Research Facility (SURF), USA. Front. Microbiol. 5, 1-14 (2014).

44. Barnhart, E. P. et al. Hydrogeochemistry and coal-associated bacterial populations from a methanogenic coal bed. Int. J. Coal Geol. 162, 14-26 (2016).

45. Foght, J. et al. Culturable Bacteria in Subglacial Sediments and Ice from Two Southern Hemisphere Glaciers. Microb. Ecol. 47, 329-40 (2004). 
46. Tillett, D. \& Neilan, B. A. Xanthogenate nucleic acid isolation from cultured and environmental cyanobacteria. J. Phycol. 36, 251-258 (2000).

47. Leuko, S. et al. Lysis efficiency of standard DNA extraction methods for Halococcus spp. in an organic rich environment. Extremophiles 12, 301-308 (2008).

48. Frank, Y. A. et al. Stable and variable parts of microbial community in Siberian deep subsurface thermal aquifer system revealed in a long-term monitoring study. Front. Microbiol. 7, 1-15 (2016).

49. Lawson, C. E. et al. Patterns of endemism and habitat selection in coalbed microbial communities. Appl. Environ. Microbiol. AEM.01737-15 (2015). doi:10.1128/AEM.01737-15

50. Bomberg, M., Lamminmäki, T. \& Itävaara, M. Microbial communities and their predicted metabolic characteristics in deep fracture groundwaters of the crystalline bedrock at Olkiluoto, Finland. Biogeosciences 13, 6031-6047 (2016).

51. Rajala, P. \& Bomberg, M. Reactivation of Deep Subsurface Microbial Community in Response to Methane or Methanol Amendment. Front. Microbiol. 08, 431 (2017).

52. Blanco, Y. et al. Deciphering the Prokaryotic Community and Metabolisms in South African Deep-Mine Biofilms through Antibody Microarrays and Graph Theory. PLoS One 9, e114180 (2014).

53. Singh, P. K., Singh, A. L., Kumar, A. \& Singh, M. P. Control of different pyrite forms on desulfurization of coal with bacteria. Fuel 106, 876-879 (2013).

54. Machnikowska, H., Pawelec, K. \& Podgórska, A. Microbial degradation of low rank coals. Fuel Process. Technol. 77-78, 17-23 (2002).

55. Lepleux, C., Turpault, M. P., Oger, P., Frey-Klett, P. \& Uroz, S. Correlation of the abundance of betaproteobacteria on mineral surfaces with mineral weathering in forest soils. Appl. Environ. Microbiol. 78, 7114-9 (2012).

56. Gründger, F. et al. Microbial methane formation in deep aquifers of a coal-bearing sedimentary basin, Germany. Front. Microbiol. 6, (2015).

57. Yagi, J. M., Sims, D., Brettin, T., Bruce, D. \& Madsen, E. L. The genome of Polaromonas naphthalenivorans strain $\mathrm{CJ} 2$, isolated from coal tar-contaminated sediment, reveals physiological and metabolic versatility and evolution through extensive horizontal gene transfer. Environ. Microbiol. 11, 2253-2270 (2009).

58. Kostka, J. E. et al. Hydrocarbon-degrading bacteria and the bacterial community response in gulf of Mexico beach sands impacted by the deepwater horizon oil spill. Appl. Environ. Microbiol. 77, 7962-74 (2011).

59. Posman, K. M., DeRito, C. M. \& Madsen, E. L. Benzene Degradation by a Variovorax Species within a Coal Tar-Contaminated Groundwater Microbial Community. Appl. Environ. 
Microbiol. 83, (2017).

60. Dürre, P. in Encyclopedia of Life Sciences 1-11 (John Wiley \& Sons, Ltd, 2015). doi:10.1002/9780470015902.a0020370.pub2

61. Jungbluth, S. P., Glavina del Rio, T., Tringe, S. G., Stepanauskas, R. \& Rappé, M. S. Genomic comparisons of a bacterial lineage that inhabits both marine and terrestrial deep subsurface systems. PeerJ 5, e3134 (2017).

62. Lollar, B. S., Onstott, T. C., Lacrampe-Couloume, G. \& Ballentine, C. J. The contribution of the Precambrian continental lithosphere to global H2 production. Nature 516, 379-382 (2014).

63. Aüllo, T., Ranchou-Peyruse, A., Ollivier, B. \& Magot, M. Desulfotomaculum spp. and

64. Stegen, J. C. et al. Coupling among Microbial Communities, Biogeochemistry, and related gram-positive sulfate-reducing bacteria in deep subsurface environments. Front. Microbiol. 4, 1-12 (2013). Mineralogy across Biogeochemical Facies. Nat. Publ. Gr. 1-14 (2016). doi:10.1038/srep30553

65. Schrenk, M. O., Brazelton, W. J. \& Lang, S. Q. Serpentinization, Carbon, and Deep Life.

66. Fredrickson, J. K. \& Balkwill, D. L. Geomicrobial Processes and Biodiversity in the Deep Terrestrial Subsurface. Geomicrobiol. J. 23, 345-356 (2006).

67. Parnell, J. \& McMahon, S. Physical and chemical controls on habitats for life in the deep

69. Wu, X. et al. Microbial metagenomes from three aquifers in the Fennoscandian shield subsurface beneath continents and ice. Philos. Trans. R. Soc. A 374, 20140293 (2016).

68. Momper, L., Jungbluth, S. P., Lee, M. D. \& Amend, J. P. Energy and carbon metabolisms in

71. Alhasawi, A., Costanzi, J., Auger, C., Appanna, N. D. \& Appanna, V. D. Metabolic terrestrial deep biosphere reveal metabolic partitioning among populations. ISME J. 10, 1192-1203 (2016).

72. Raiger Iustman, L. J. et al. Genome sequence analysis of Pseudomonas extremaustralis provides new insights into environmental adaptability and extreme conditions resistance. Extremophiles 19, 207-220 (2015). 
73. Uroz, S., Calvaruso, C., Turpault, M.-P. P. \& Frey-Klett, P. Mineral weathering by bacteria: ecology, actors and mechanisms. Trends Microbiol. 17, 378-387 (2009).

74. Rosenberg, E. in The Prokaryotes: Alphaproteobacteria and Betaproteobacteria 1-1012 (2013). doi:10.1007/978-3-642-30197-1

75. Onstott, T. C. et al. Indigenous and contaminant microbes in ultradeep mines. Environ. Microbiol. 5, 1168-1191 (2003).

76. Davidson, M. M. et al. Capture of Planktonic Microbial Diversity in Fractures by Long-Term Monitoring of Flowing Boreholes, Evander Basin, South Africa. Geomicrobiol. J. 28, 275300 (2011).

77. Salter, S. J. et al. Reagent and laboratory contamination can critically impact sequence-based microbiome analyses. BMC Biol. 12, 87 (2014).

78. Puente-Sánchez, F. et al. Viable cyanobacteria in the deep continental subsurface. PNAS (2018). doi:10.1073/pnas.1808176115

79. Di Rienzi, S. C. et al. The human gut and groundwater harbor non-photosynthetic bacteria belonging to a new candidate phylum sibling to Cyanobacteria. Elife 2, e01102 (2013).

80. Sogin, M. \& Edwards, K. Deep Subsurface Microbiology and the Deep Carbon Observatory. in DCO Deep Life Workshop (2010).

81. Davis, N. M., Proctor, D., Holmes, S. P., Relman, D. A. \& Callahan, B. J. Simple statistical identification and removal of contaminant sequences in marker-gene and metagenomics data. bioRxiv 221499 (2018). doi:10.1101/221499

82. Direito, S. O. L., Marees, A. \& Röling, W. F. M. Sensitive life detection strategies for lowbiomass environments: Optimizing extraction of nucleic acids adsorbing to terrestrial and Mars analogue minerals. FEMS Microbiol. Ecol. 81, 111-123 (2012).

83. Karst, S. M. et al. Retrieval of a million high-quality, full-length microbial $16 \mathrm{~S}$ and $18 \mathrm{~S}$ rRNA gene sequences without primer bias. Nat. Biotechnol. 36, 190-195 (2018).

84. Martijn, J. et al. Amplicon sequencing of the 16S-ITS-23S rRNA operon with long-read technology for improved phylogenetic classification of uncultured prokaryotes. bioRxiv 234690 (2017). doi:10.1101/234690

85. Fierer, N. \& Cary, C. Don't let microbial samples perish. Nature 512, 253-253 (2014).

86. Caporaso, J. G. et al. QIIME allows analysis of high-throughput community sequencing data. Nat. Methods 7, 335-336 (2010).

87. Edgar, R. C. Search and clustering orders of magnitude faster than BLAST. 26, 2460-2461 (2010).

88. McMurdie, P. J. \& Holmes, S. Phyloseq: An R Package for Reproducible Interactive Analysis and Graphics of Microbiome Census Data. PLoS One 8, e61217 (2013). 
592 89. Wickham, H. \& Chang, W. ggplot2: An Implementation of the Grammar of Graphics. $593 \quad$ (2015).

594 90. R Development Core Team. R: A language and environment for statistical computing. (2008).

596 91. Dixon, P. VEGAN, a package of R functions for community ecology. J. Veg. Sci. 14, 927$597 \quad 930(2003)$.

598 92. Fuglede, B. \& Topsoe, F. Jensen-Shannon divergence and Hilbert space embedding. in 599 International Symposium onInformation Theory, 2004. ISIT 2004. Proceedings. 30-30 (IEEE, 2004). doi:10.1109/ISIT.2004.1365067 
602 Acknowledgements

603 The work was funded by a National Research Network for Low Carbon Energy and Environment 604 (NRN-LCEE) grant to ACM and AE from the Welsh Government and the Higher Education Funding 605 Council for Wales (Geo-Carb-Cymru). Deep borehole samples from Nevada and California, USA 606 (e.g. Nevares Deep Well 2 and BLM-1) were obtained with help in the field from Alexandra 607 Wheatley, Jim Bruckner, Jenny fisher and Scott Hamilton-Brehm, and technical assistance and 608 funding from the US Department of Energy's Subsurface Biogeochemical Research Program, the 609 Hydrodynamic Group, LLC, the Nye County Nuclear Waste Repository Program Office (NWRPO), 610 the US National Park Service, and Inyo Country, CA. Samples from a mine in Northern Ontario 611 Canada were obtained with funding from the Natural Sciences and Engineering Research Council of 612 Canada and the assistance of Thomas Eckert, and Greg Slater of McMaster University. The Census 613 of Deep Life (CoDL) and Deep Carbon Observatory (DCO) projects are acknowledged for a range 614 of studies used in this analysis, as well as the sequencing team at the Marine Biological Laboratory 615 (MBL). Disclaimer: Any use of trade, firm, or product names is for descriptive purposes only and 616 does not imply endorsement by the U.S. Government.

618 Author Contributions

619 ARS developed the methodology, collated and analysed the data, and wrote the manuscript. AE and 620 AM conceived the study, supervised AS and helped write the manuscript. Other authors provided 621 data from field sites used in the global meta-analysis. All authors contributed, edited and approved 622 the final manuscript.

\section{Conflict of Interest}

625 We declare no conflict of interest. 


\section{Supplementary Information - "A global perspective on}

\section{2 microbial diversity in the terrestrial deep subsurface"}

3

4 Authors:

5 Soares, A. ${ }^{1,2,3}$, Edwards, A. ${ }^{2,3^{*}}$, An, D. ${ }^{4}$, Bagnoud, A. ${ }^{5}$, Barnhart, E ${ }^{6,7}$, Bomberg, M. ${ }^{8}$, Budwill, K. ${ }^{9}$, 6 Caffrey, S. ${ }^{10}$, Fields, M. ${ }^{7}$, Gralnick., J. ${ }^{11}$, Kadnikov, V. ${ }^{12,13}$, Momper, L. ${ }^{14}$, Osburn, M. ${ }^{15}$, Mu, 7 A. ${ }^{16,17,18,19}$, Moreau, J.W. ${ }^{16}$, Moser, D. ${ }^{20}$, Purkamo, L. ${ }^{8,21,22}$, Rassner, S. M. ${ }^{1,3}$, Sheik, C. S. ${ }^{23}$, 8 Sherwood Lollar, B. ${ }^{24}$, Toner, B. M. ${ }^{25}$, Voordouw, G. ${ }^{4}$, Wouters, K. ${ }^{26}$, Mitchell, A. C. ${ }^{1,3^{*}}$ 


\section{Supplementary Text}

\section{Depth weakly controls microbial community structure}

13 Life at extreme depths is yet to be analysed at a deep genomic level, but microbial cells have been discovered at depths down to $3,6 \mathrm{~km}$ in the terrestrial crust ${ }^{1,2}$. Although cell numbers tend to decrease with depth in both crystalline and sedimentary rock in the continental crust, not much is known regarding large-scale taxonomic trends ${ }^{2}$. No significant correlations were found for the presence of the most abundant clades in the dataset and depth, being Actinobacteria the only major taxonomic group to have a positive, albeit weak, correlation to depth (Pearson's $r=0.42, \mathrm{p}<0.01$, Figure S2). Actinobacteria have already been detected at great depths in both the continental and oceanic crusts and some of its members have further been reported to hold ancestral genes for pyruvate oxidoreductase activity, which could potentially propel microbial growth at higher temperatures ${ }^{3,4}$. Proportions of Beta- and Gammaproteobacteria decreased with depth (Pearson's $r=-0.29$, Pearson's $r=-0.093)$, and no other major clades were shown to correlate. More data needs to be generated to better investigate which, if any, taxonomic groups prefer deeper terrestrial environments. Biochemical limitations to life such as racemization rates of organic acids with depth and temperature will surely select for adaptable taxa and possibly create a mostly depth-defined gradient of representation of adapted extremophilic clades ${ }^{5}$.

\section{9\% closed-reference OTU analysis}

30 A 99\% similarity closed-reference OTU-picking strategy to further minimize potential contamination

31 showed a $\sim 10$-fold decrease in the number of OTUs and read numbers (1,065 OTUs and 70,527 reads were left). Further, this reduced the number of retrieved samples to 93.

33 Following the previously described filtering steps (hold only OTUs represented by more than 500 sequences and present in at least 10 samples), 335 OTUs (67,151 reads) associated to 14 samples were left. For this reduced dataset, 2 OTUs associated to Chloroplast were found, represented by 115 sequences in total. The very reduced number of samples, OTUs an total reads left in the datasset caused the $99 \%$ OTU approach to be discontinued. 


\section{Supplementary Methodology}

41 Phylogeny of Pseudomonas representative sequences

42 Representative 16S rRNA gene sequences for Pseudomonas OTUs in the dataset were isolated by 43 retrieving OTU IDs affiliated to this genus in the final dataset using the subset_taxa function within 44 phyloseq ${ }^{6}$. The SILVA 123 database was then queried against the list of OTU IDs and the results 45 deposited in a FASTA file. Outgroup sequences of genus Sphingomonas (Proteobacteria, 46 Alphaproteobacteria, Sphingomonadales, Sphingomonadaceae) were obtained directly from the 47 SILVA database (https://www.arb-silva.de/) and added along with the retrieved Pseudomonas 16S 48 rRNA gene sequences to a final FASTA file.

49 Using MEGA7 7 , an alignment was performed using the MUSCLE ${ }^{8}$ algorithm and 8 iterations of the 50 UPGMB (combines Neighbour-Joining 9 and UPGMA - Unweighted Pair Group Method with 51 Arithmetic mean) clustering method. An optimal Neighbour-Joining ${ }^{9}$ tree ( $c f$. Supplementary 52 Figure 4) was then created using 500 bootstrapped replicates and the Maximum Composite 53 Likelihood (MCL) ${ }^{10}$ method to calculate evolutionary distances. 


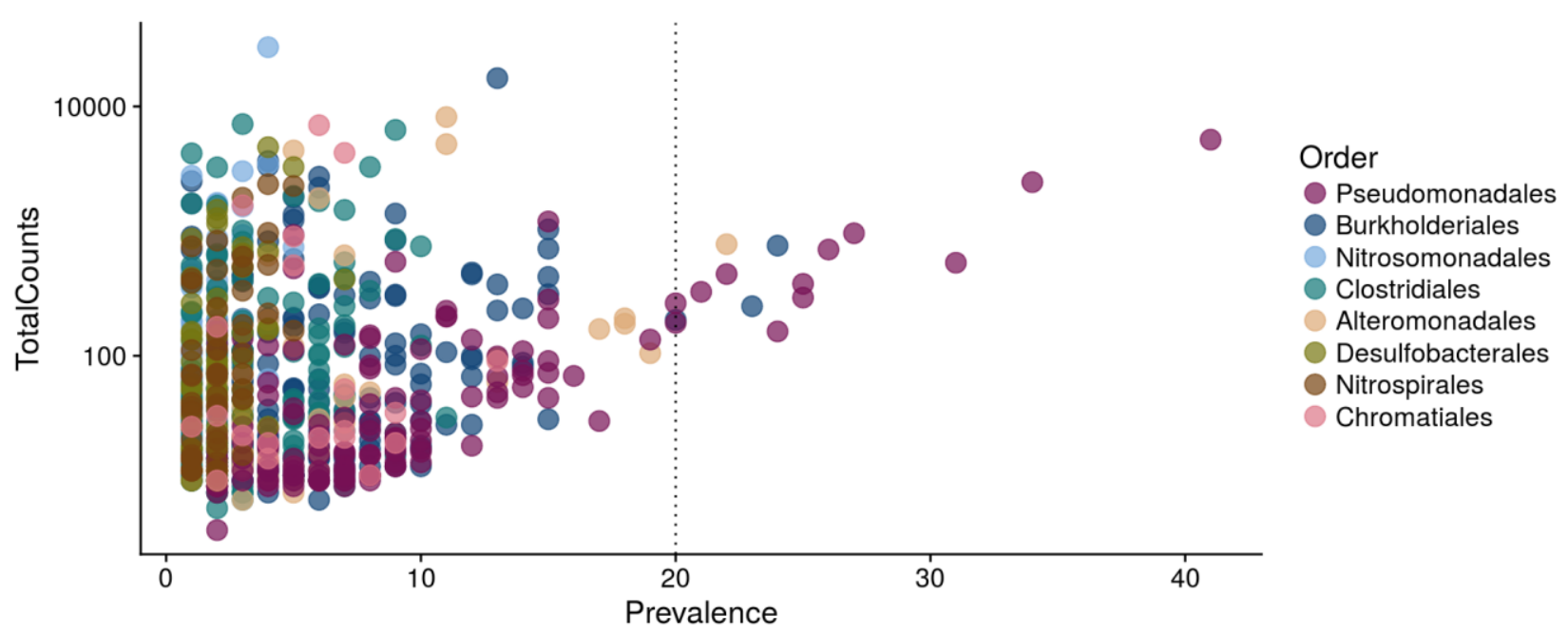

Supplementary Figure 1 - Prevalence (number of samples an OTU is present in, X-axis) of OTUs across the dataset and associated reads (y-axis). Colours depict classification of OTUs at order level. Vertical line crosses 20 samples in the $\mathrm{x}$-axis to highlight OTUs present in 20 or more samples.

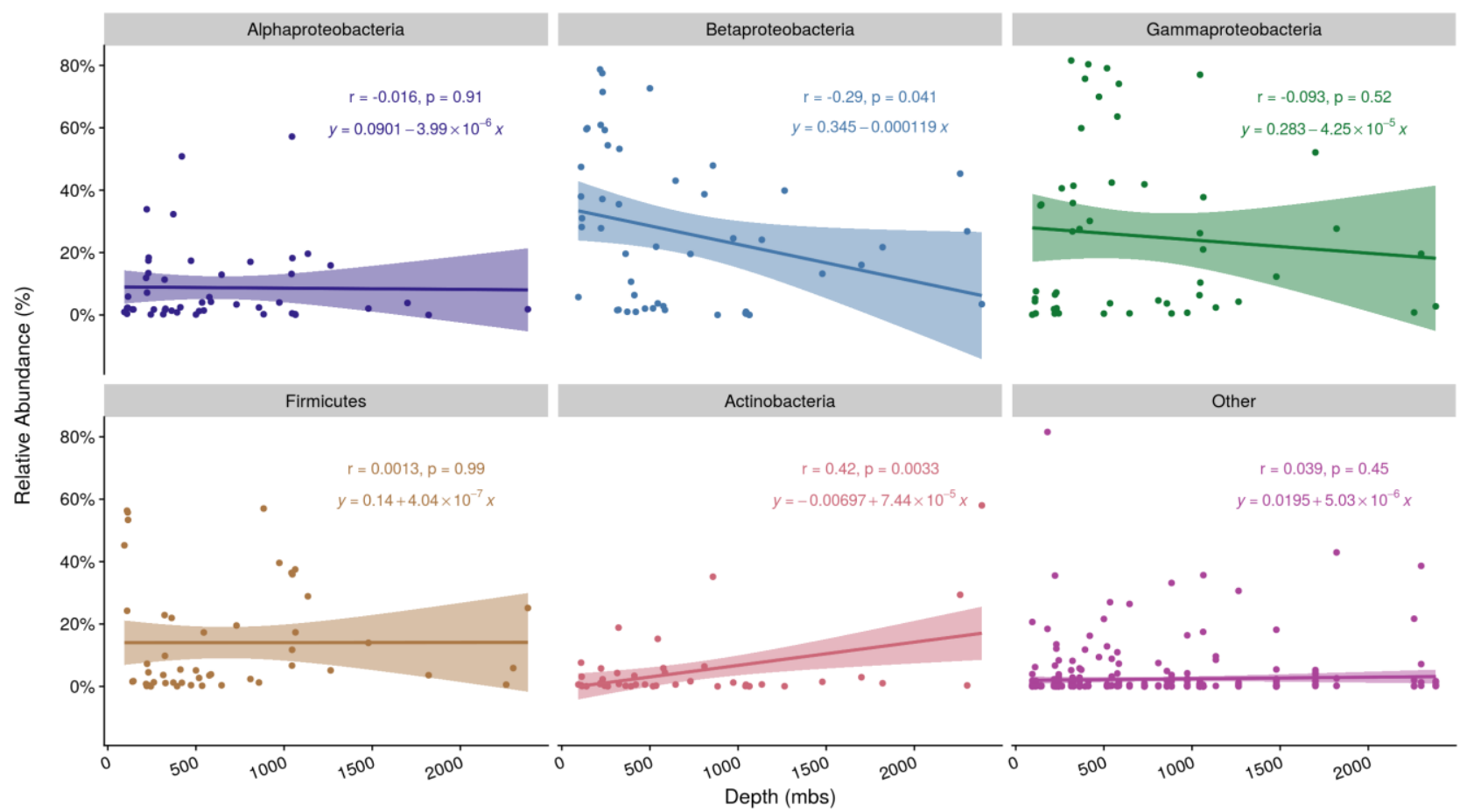

61 Supplementary Figure 2 - Correlations between relative abundance of OTUs (\%, y-axis) associated to the most abundant taxonomic groups across the dataset and depth (meters below surface, $\mathrm{x}$-axis).

63 Regression lines follow the linear model and shading around lines corresponds to the 95\% confidence 64 interval. Annotations in plot facets indicate the associated Pearson correlation coefficient, its corresponding p-value and the fitted linear model equation. Each point represents an OTU associated to the taxonomic group in each facet at a certain depth - a same OTU may be depicted more than one time. 


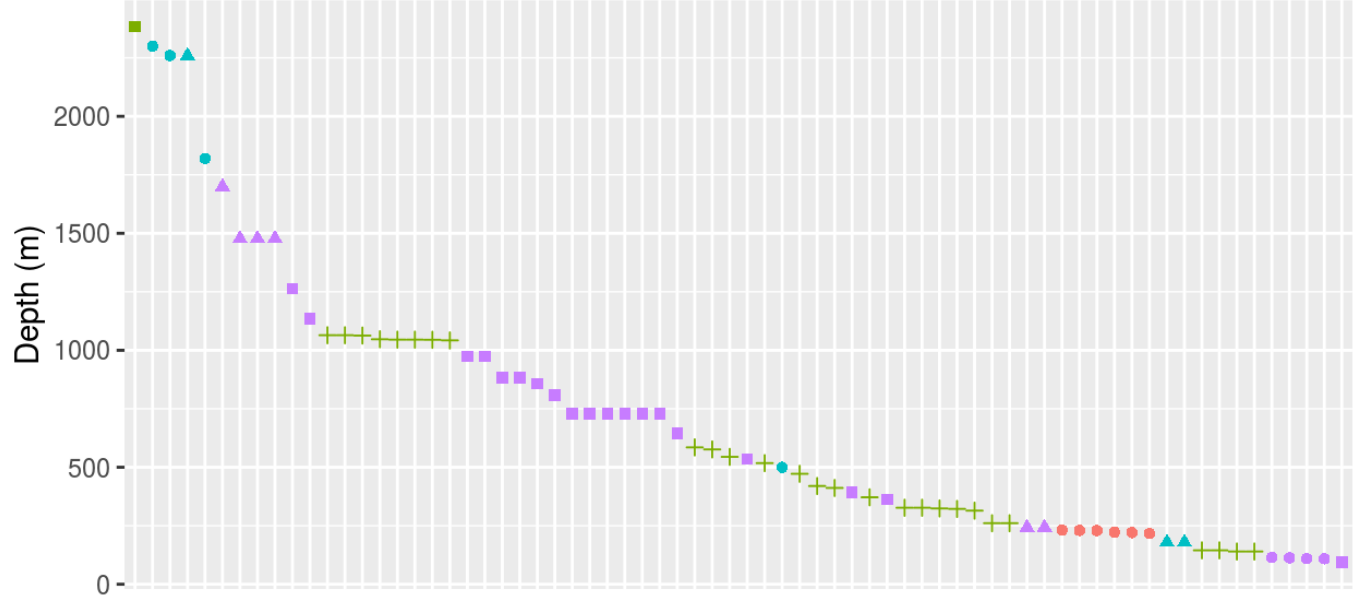

- $\mathrm{V} 1-\mathrm{V} 3$

- V4

- V4-V6

$+\mathrm{V} 6-\mathrm{V} 8$

Location

- Belgium

Canada

- Finland

- USA

69 Supplementary Figure 3 - Distribution of samples in the final dataset across depth, colourised by 70 general location. Shapes indicate 16S rRNA gene region utilised for that study. 


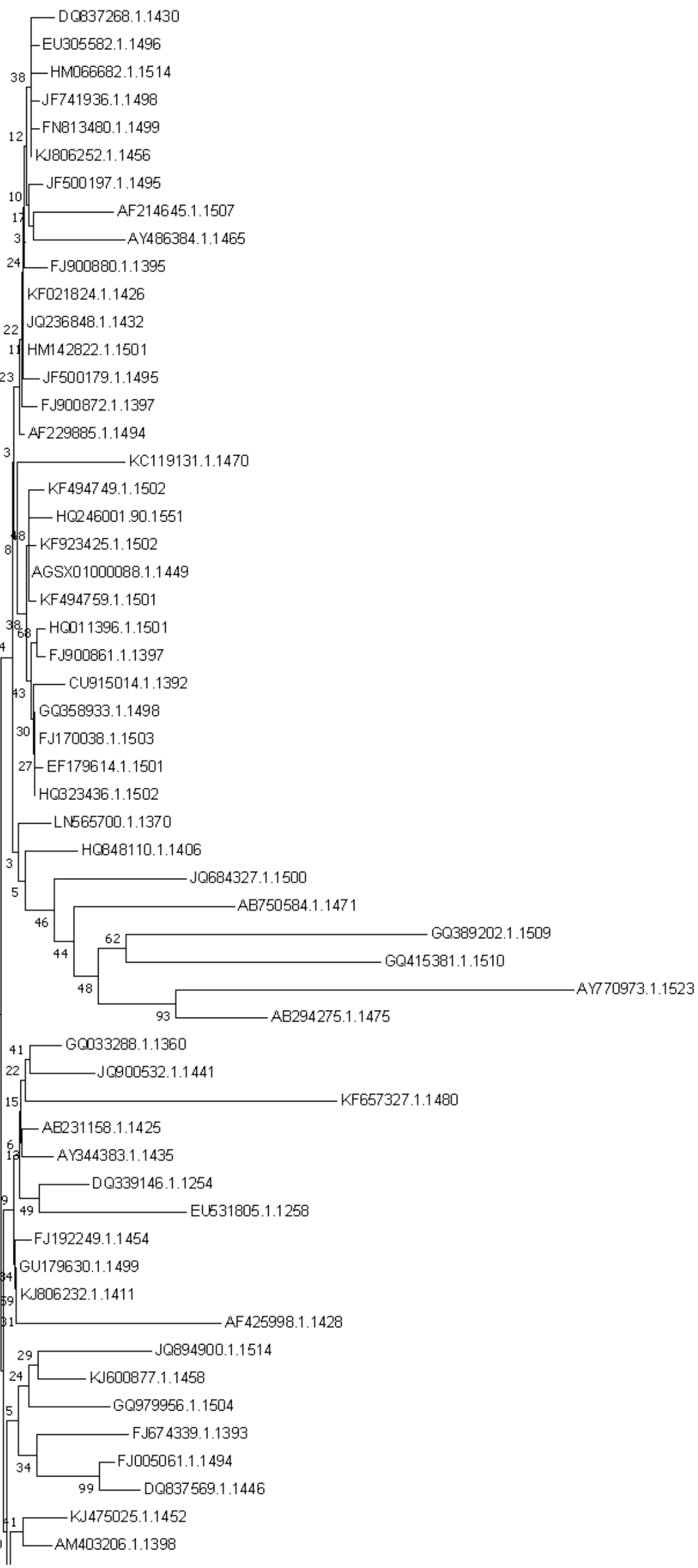




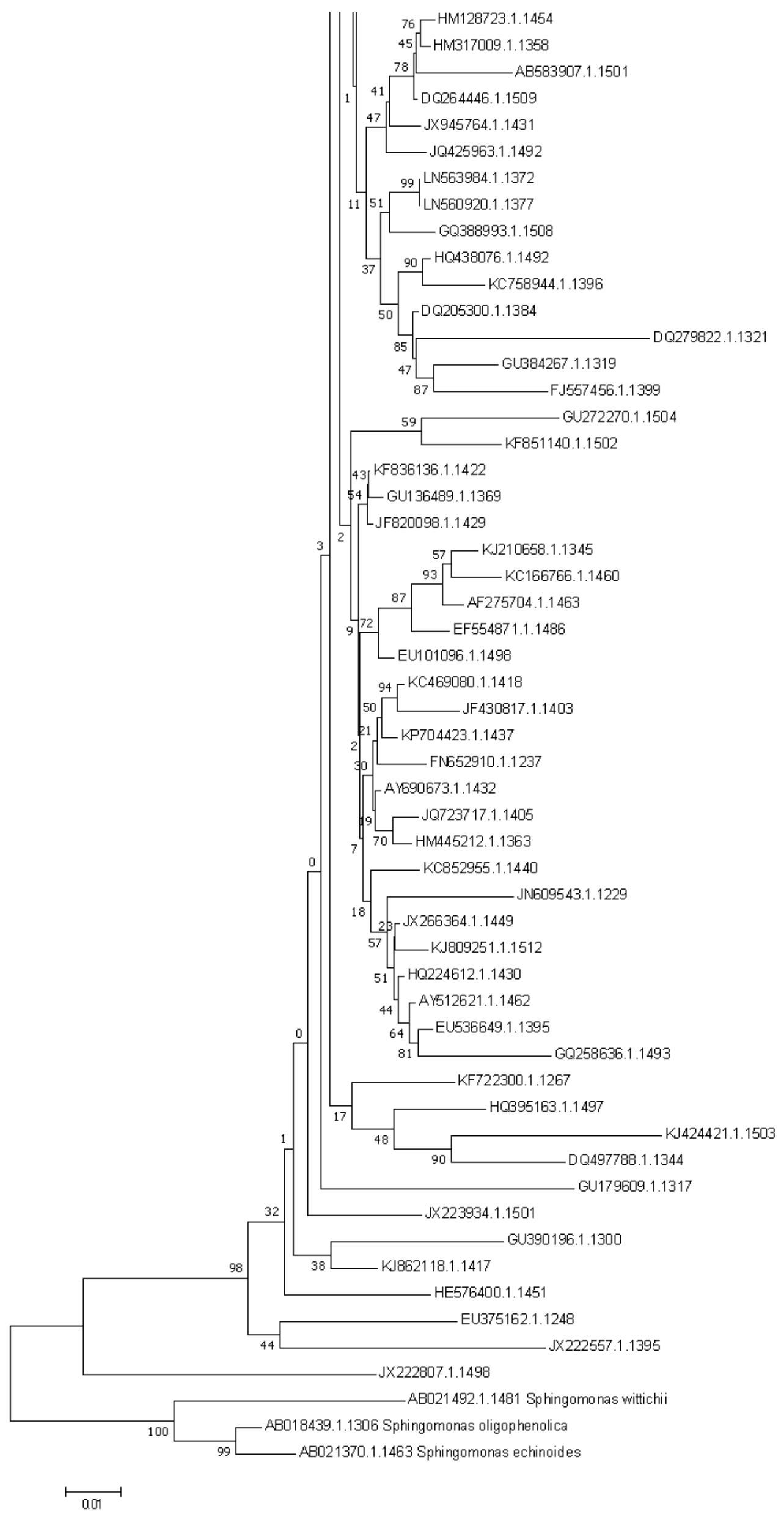


74 Supplementary Figure 4 - Optimal Neighbor-Joining tree of representative sequences for 75 Pseudomonas OTUs in the dataset following MUSCLE aligment. OTU IDs are shown in the end of 76 each branch and outgroup sequences of genus Sphingomonas identified by their taxonomic affiliation. 77 The percentage of bootstrap test replicates are shown next to tree branches and scale for MCL evolutionary distances is shown in the bottom. 


\section{Supplementary Tables}

81 Supplementary Table 1 - Top 10 OTU network interactions ordered by edge betweenness (number of shortest paths going through an edge - OTU/OTU 82 interactions) values as per the calculated Jaccard distances.

\begin{tabular}{ll}
\multicolumn{1}{c}{ OTU 1 Classification } & \multicolumn{1}{c}{ OTU 2 Classification } \\
\hline Gammaproteobacteria, Chromatiales, Chromatiaceae, Rheinheimera & Gammaproteobacteria, Chromatiales, Chromatiaceae, Rheinheimera \\
\hline Gammaproteobacteria, Chromatiales, Chromatiaceae, Rheinheimera & Gammaproteobacteria, Pseudomonadales, Moraxellaceae, Acinetobacter \\
\hline Gammaproteobacteria, Chromatiales, Chromatiaceae, Rheinheimera & Gammaproteobacteria, Alteromonadales, Alteromonadaceae, Alishewanella \\
\hline Gammaproteobacteria, Pseudomonadales, Pseudomonadaceae, Pseudomonas & Gammaproteobacteria, Chromatiales, Chromatiaceae, Rheinheimera \\
\hline Gammaproteobacteria, Pseudomonadales, Pseudomonadaceae, Pseudomonas & Gammaproteobacteria, Chromatiales, Chromatiaceae, Rheinheimera \\
\hline Betaproteobacteria., Rhodocyclales, Rhodocyclaceae, Azoarcus & Betaproteobacteria, Rhodocyclales, Rhodocyclaceae, uncultured \\
\hline Firmicutes, Clostridia, Clostridiales, Peptostreptococcaceae, Peptoclostridium & Firmicutes, Clostridia, Clostridiales, Peptostreptococcaceae, Intestinibacter \\
\hline Gammaproteobacteria, Pseudomonadales, Pseudomonadaceae, Pseudomonas & Alphaproteobacteria, Rhodobacterales, Rhodobacteraceae, Paracocccus \\
\hline Gammaproteobacteria, Chromatiales, Chromatiaceae, Rheinheimera & Gammaproteobacteria, Alteromonadales, Alteromonadaceae, Alishewanella \\
\hline Gammaproteobacteria, Pseudomonadales, Moraxellaceae, Acinetobacter & Gammaproteobacteria, Pseudomonadales, Moraxellaceae, Acinetobacter \\
\hline 499.26
\end{tabular}


85 Supplementary Table 2 - SILVA 123 taxonomic affiliations of OTUs present in 20 or more samples. Prevalence is defined as the number of samples an OTU is present in.

Taxa ID Taxa Classification Prevalence

\begin{tabular}{|c|c|c|}
\hline JQ236848.1.1432 & Proteobacteria, Gammaproteobacteria, Pseudomonadales, Pseudomonadaceae, Pseudomonas & 41 \\
\hline HM142822.1.1501 & Proteobacteria, Gammaproteobacteria, Pseudomonadales, Pseudomonadaceae, Pseudomonas & 34 \\
\hline JX266364.1.1449 & Proteobacteria, Gammaproteobacteria, Pseudomonadales, Pseudomonadaceae, Pseudomonas & 31 \\
\hline KJ475025.1.1452 & Proteobacteria, Gammaproteobacteria, Pseudomonadales, Pseudomonadaceae, Pseudomonas & 27 \\
\hline FJ192249.1.1454 & Proteobacteria, Gammaproteobacteria, Pseudomonadales, Pseudomonadaceae, Pseudomonas & 26 \\
\hline HQ848110.1.1406 & Proteobacteria, Gammaproteobacteria, Pseudomonadales, Pseudomonadaceae, Pseudomonas & 25 \\
\hline KC852955.1.1440 & Proteobacteria, Gammaproteobacteria, Pseudomonadales, Pseudomonadaceae, Pseudomonas & 25 \\
\hline HM773515.1.1498 & Proteobacteria, Betaproteobacteria, Burkholderiales, Comamonadaceae, uncultured & 24 \\
\hline $\mathrm{AB} 231158.1 .1425$ & Proteobacteria, Gammaproteobacteria, Pseudomonadales, Pseudomonadaceae, Pseudomonas & 24 \\
\hline JX222276.1.1475 & Proteobacteria, Betaproteobacteria, Burkholderiales, Comamonadaceae, Variovorax & 23 \\
\hline EU841498.1.1443 & Proteobacteria; Gammaproteobacteria; Alteromonadales, Alteromonadaceae, Alishewanella & 22 \\
\hline EU305582.1.1496 & Proteobacteria, Gammaproteobacteria, Pseudomonadales, Pseudomonadaceae, Pseudomonas & 22 \\
\hline FJ900880.1.1395 & Proteobacteria, Gammaproteobacteria, Pseudomonadales, Pseudomonadaceae, Pseudomonas & 21 \\
\hline
\end{tabular}


88 Supplementary Table 3 - Metadata table with complete details for all studies utilized.

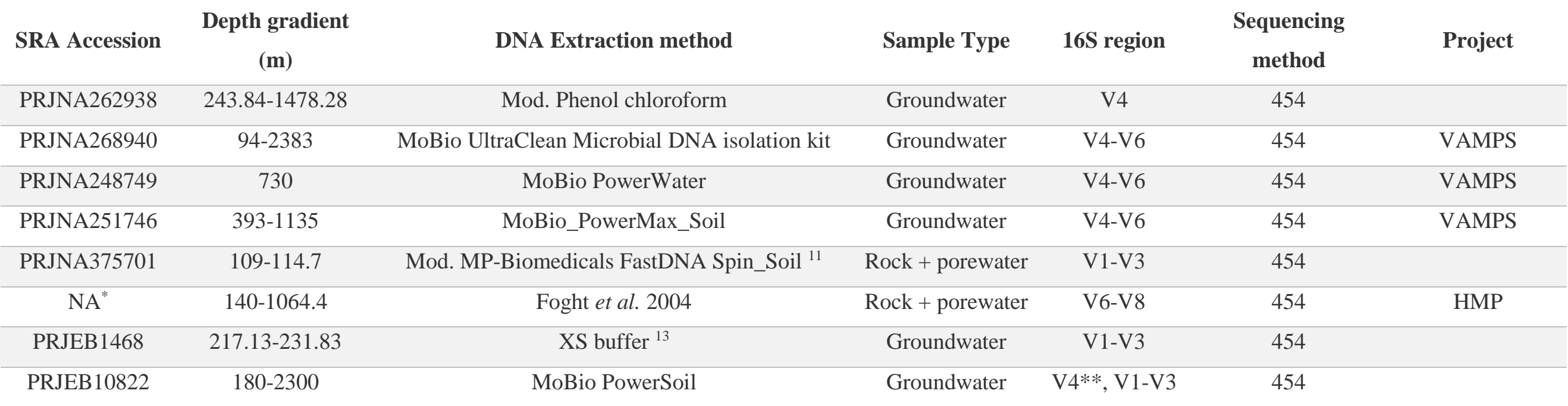

$90 *$ http://hmp.ucalgary.ca/HMP/

$91 *$ This primer pair corresponds to archaeal 16S rRNA gene primers (A344,A744, cf. 10.5194/bg-13-3091-2016 for further details). 


\begin{tabular}{|c|c|c|c|c|c|c|c|c|c|c|}
\hline отU ID & \begin{tabular}{|c|} 
Closest BLAST hit \\
\end{tabular} & \begin{tabular}{|c|} 
Associated NCBI Title \\
\end{tabular} & Associated Environment & Taxonomy ID & NCBI Accession & \begin{tabular}{|c} 
Percent similarity \\
$(\%)$
\end{tabular} & E-value & $\begin{array}{c}\text { No. Samples } \\
\text { Associated }\end{array}$ & $\begin{array}{l}\text { No. Reads } \\
\text { Associated }\end{array}$ & Observations \\
\hline AB231158.1.1425 & $\begin{array}{l}\text { Pseudomonas pseudoalcaligenes gene for } 16 \mathrm{~S} \mathrm{rRNA}, \\
\text { partial sequence }\end{array}$ & $\begin{array}{l}\text { High nitrogen removal from wastewater with several new } \\
\text { aerobic bacteria isolated from diverse ecosystems }\end{array}$ & Wastewater & 330 & gi|85539942|dbj|AB231158.1] & 100 & 0 & 24 & 157 & \\
\hline AB294275.1.1475 & 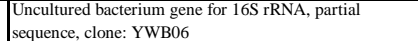 & $\begin{array}{l}\text { Molecular characterization of microbial communities in deep } \\
\text { coal seam groundwater of northern Japan }\end{array}$ & Subsurface & 77133 & gi|126143387/dbb|AB294275.11 & 100 & 0 & 19 & 135 & \\
\hline AB583907.1.1501 & $\begin{array}{l}\text { Uncultured bacterium gene for } 16 \mathrm{~S} \text { rRNA, clone: } \mathrm{RBC}- \\
4 \mathrm{~B}\end{array}$ & \begin{tabular}{|l|} 
Microbial community in water-rock-microbe interaction \\
systems in subsurface environments
\end{tabular} & Subsurface & 77133 & gi|324604950||dbj|ABS583907.1] & 100 & 0 & 3 & 137 & \\
\hline AB750584.1.1471 & \begin{tabular}{|l|} 
Uncultured bacterium gene for $16 \mathrm{~S}$ rRNA, partial \\
sequence, clone: 23 hydrate.Cas. $16 \mathrm{~S}$
\end{tabular} & $\begin{array}{l}\text { Novel integrons and gene cassettes from a Cascadian } \\
\text { submarine gas hydrate-bearing core }\end{array}$ & Subsurface & 77133 & [gi|407969505|dbj|AB750584.1] & 100 & 0 & 16 & 69 & \\
\hline AF214645.1.1507 & $\begin{array}{l}\text { Nitrogen-fixing bacterium MIS } 16 \text { S ribosomal RNA } \\
\text { gene, partial sequence }\end{array}$ & $\begin{array}{l}\text { Molecular characterization of plant associated nitrogen-fixing } \\
\text { Bacteria }\end{array}$ & Subsurface & 120486 & $\begin{array}{l}5 \\
5\end{array}$ & 100 & 0 & 4 & 20 & \\
\hline AF229885.1.1494 & $\begin{array}{l}\text { Pseuddomonas sp. 3CB6 16S ribosomal RNA gene, partial } \\
\text { sequence }\end{array}$ & $\begin{array}{l}\text { Issalation and characterization of diverse halobenzoate- } \\
\text { degrading denitrifying bacteria from soils and sediments }\end{array}$ & Subsurface & 126132 & gi|9965646|gb|AF229885.1] & 100 & 0 & 9 & 22 & \\
\hline AF275704.1.1463 & \begin{tabular}{|l} 
Unidentified Hailaer sodad lake bacterium F5 165 \\
ribosonal RNA gene, partial sequence
\end{tabular} & China: Inner Mongolia & Lake & 148462 & 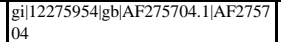 & 100 & 0 & 12 & 47 & \\
\hline AF425998.1.1428 & \begin{tabular}{|l}
$\begin{array}{l}\text { Bacterium UNSW3 } 16 S \text { ribosomal RNA gene, partial } \\
\text { sequence }\end{array}$ \\
s.
\end{tabular} & $\begin{array}{l}\text { A survey of hhlygong and paralytyic shellfish poison } \\
\text { production from culturable bacteria associated with a toxic } \\
\text { Anabaena circinalis strain }\end{array}$ & Host-associated & 190587 & gi|23451685|gb|AF425998.1] & 100 & 0 & 14 & 56 & \\
\hline AGSX01000088.1.1449 & $\begin{array}{l}\text { Pseudomonas stutzeri SDM-LAC contig000089, whole } \\
\text { genome shotgun sequence }\end{array}$ & $\begin{array}{l}\text { Genome Sequence of Psesdomomans stutzrer SDM-ACAC, a } \\
\text { Typical Strain for Studying the Molecular Mechanism of } \\
\text { Lactate Utilization }\end{array}$ & Lab strain & 271420 & gi|1093258265|emb|LT629970.1| & 99.83 & 0 & 6 & 28 & \\
\hline AM403206.1.1398 & \begin{tabular}{|l|}
$\begin{array}{l}\text { seudomonadaceae bacterium D7-21 partial } 16 \mathrm{~S} \text { rRNA } \\
\text { gene, isolate D7-21 }\end{array}$ \\
\end{tabular} & $\begin{array}{l}\text { Diversity of Nitrate-reducing and Denitrifying Bacteria in a } \\
\text { Marine Aquaculture Biofilter }\end{array}$ & Seawater & 404904 & gi|l1153340066lemb|AM403206.11 & 100 & 0 & 8 & 16 & \\
\hline AY344383.1.1435 & $\begin{array}{l}\text { Unidentifified bacterium clone K2-4-3 } 165 \text { ribosomal } \\
\text { RNA gene, partial sequence }\end{array}$ & $\begin{array}{l}\text { Microbial Communities in the Hawaiian Archipelago: A } \\
\text { Microbial Diversity Hotspot }\end{array}$ & Subsurface & 1869227 & gi|33391921|gb|AY344383.1| & 100 & 0 & 6 & 10 & \\
\hline AY486384.1.1465 & $\begin{array}{l}\text { Pseudomonas stutzeri strain AU4823 } 165 \text { ribosomal } \\
\text { RNA gene, partial sequence }\end{array}$ & $\begin{array}{l}\text { PCR-based assay for differentiation of Pseudomonas acruginosa } \\
\text { from other sseudomonas species recovered from cystic fibrosis } \\
\text { patients }\end{array}$ & Host-associated & 316 & gi|40019083.gb|AY486384.1] & 100 & 0 & 7 & 17 & \\
\hline AY512621.1.1462 & $\begin{array}{l}\text { Pseudomonas veronii strain A1YABTEX2-5 } 16 \mathrm{~S} \\
\text { ribosomal RNA gene, partial sequence }\end{array}$ & $\begin{array}{l}\text { Alternative primer sets for PCR detection of genotypes } \\
\text { involved in bacterial aerobic } \mathrm{BTEX} \text { degradation distribution of } \\
\text { the genes in BTEX degrading isolates and in subsurface soils } \\
\text { of a BTEX contaminated industrial site }\end{array}$ & Subsurface & 76761 & $\mathrm{gi}|41056888 \mathrm{gb|}| \mathrm{AY} 512621.1]$ & 100 & 0 & 15 & 91 & \\
\hline AY690673.1.1432 & $\begin{array}{l}\text { Sulfitobacter sp. GC07 } 165 \text { ribosomal RNA gene, partial } \\
\text { sequence }\end{array}$ & $\begin{array}{l}\text { The diversitit of halototeranth theterotrophic bacteria isolated } \\
\text { from rhizosphere soil of salt marshes from southwestern coasts } \\
\text { in Korea }\end{array}$ & Subsurface & 290364 & gi|51243779|gb|AY690673.1| & 100 & 0 & 1 & 33 & $\begin{array}{l}\text { Latets IIVVA databasa classifies } \\
\text { this sequence as genus } \\
\text { Psendomonas }\end{array}$ \\
\hline AY770973.1.1523 & \begin{tabular}{|l|} 
Uncultured bacterium clone W33 165 ribosomal RNA \\
gene, partial sequence
\end{tabular} & Molecular analysis of the microbial communities of the oilfield & Subsurface & 77133 & gi| 14695050 |gb|AY770073.1| & 100 & 0 & 10 & 14 & \\
\hline CU915014.1.1392 & 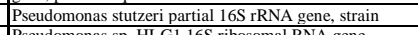 & \begin{tabular}{|l|} 
marine sediment and soils \\
\end{tabular} & Subsurface & 77133 & 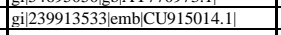 & 100 & 0 & 2 & 13 & \\
\hline DQ205300.1.1384 & $\begin{array}{l}\text { 食eudomononas sp. HI-G1 16S ribosomal RNA gene, } \\
\text { partial sequence }\end{array}$ & $\begin{array}{l}\text { Culturable microbial diversity and the impact of tourism in } \\
\text { Kartchner Caverns, Arizona }\end{array}$ & Subsurface & 347772 & gi| $763655859 \mathrm{gb|} \mid \mathrm{DQ} 205300.1]$ & 100 & 0 & 2 & 15 & \\
\hline DQ264446.1.1509 & $\begin{array}{l}\text { Uncultured bacterium clone BANW452 16S ribosomal } \\
\text { RNA gene, partial sequence }\end{array}$ & $\begin{array}{l}\text { High-density unisersal } 16 \mathrm{~S} \text { r rNA microarray analysis reveals } \\
\text { broder diversity than typical clone library when sampling the } \\
\text { environment }\end{array}$ & Subsurface & 77133 & gi|82393910|gb|DQ264446.1| & 100 & 0 & 5 & 13 & \\
\hline DQ279822.1.1321 & Pseudomonas sp. D14 165 r ribosomal RNA gene, partial & Direct Submission, strain D14 & Lab strain & 358759 & 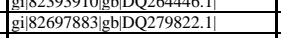 & 100 & 0 & 6 & 10 & \\
\hline DQ339146.1.1254 & \begin{tabular}{|l|}
$\begin{array}{l}\text { Pseudomonas sp. M99918 } 16 \text { S ribosomal RNA gene, } \\
\text { partial seuence }\end{array}$ \\
\end{tabular} & 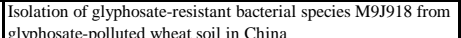 & Subsurface & 366287 & 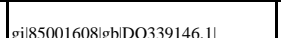 & 100 & 0 & 9 & 13 & \\
\hline DQ497788.1.1344 & $\begin{array}{l}\text { Pseudomonas sp. SGb396 } 16 \text { S ribosomal RNA gene, } \\
\text { Pros Ren }\end{array}$ & Soil, subussfface, bacterial endophytes from Taxus globosa & Subsurface & 77133 & 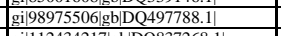 & 100 & 0 & 10 & 44 & \\
\hline DQ837268.1.1430 & 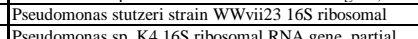 & \begin{tabular}{|l|} 
Wastewater in lagos and ogun states Nigeria \\
Direct Submission isolate K4
\end{tabular} & Wastewater & 86473 & 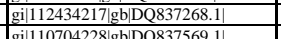 & 100 & $\frac{0}{0}$ & $\frac{7}{9}$ & $\frac{16}{18}$ & \\
\hline $\begin{array}{l}\text { DQ8375699.1.1.1466 } \\
\text { EF179614.1.1501 } \\
\end{array}$ & 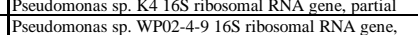 & $\begin{array}{l}\text { Direct tubmissioio, isilate K4 } \\
\text { IIsolation from deep-sea sediments }\end{array}$ & $\begin{array}{l}\text { Lab straan } \\
\text { Subsurface }\end{array}$ & $\frac{394445}{444156}$ & 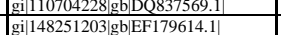 & $\frac{100}{100}$ & $\frac{0}{0}$ & $\frac{9}{2}$ & $\frac{18}{4}$ & \\
\hline EF554871.1.1486 & $\begin{array}{l}\begin{array}{l}\text { Pseudomonas sp. AB42 } 16 S \text { ribosomal RNA gene, partial } \\
\text { sequence }\end{array} \\
\end{array}$ & $\begin{array}{l}\text { Adaptative Potential of Alkaliphilic Bacteria towards } \\
\text { Chloroaromatic Substrates Assessed by a gfp-Tagged 2,4-D } \\
\text { Degradation Plasmid }\end{array}$ & Lake & $\begin{array}{c}443000 ; 443001 ; 443 \\
002 ; 1740285\end{array}$ & gil 146747229 gb|EF554868.11 & 100 & 0 & 9 & 46 & \\
\hline EU101096.1.1498 & $\begin{array}{l}\text { Uncultured bacterium clone FS0612_B12 } 16 \text { S ribosomal } \\
\text { RNA gene, partial sequence }\end{array}$ & $\begin{array}{l}\text { Niche differentiation among sulfur-oxidizing bacterial } \\
\text { populations in cave waters }\end{array}$ & Subsurface & 77133 & gi|156573149|gb|EU101096.1] & 100 & 0 & 5 & 12 & \\
\hline EU305582.1.1496 & $\begin{array}{l}\text { Uncultured Pseudomonas sp. clone 3-A 16S ribosomal } \\
\text { RNA gene, partial sequence }\end{array}$ & $\begin{array}{l}\text { Nitrtite removal performance and communutity structure of nitrite- } \\
\text { oxidizing and heterotrophic bacteria suffered with organic } \\
\text { Matter }\end{array}$ & Microcosm & 114707 & gil163676410|gb|EU305582.11 & 100 & 0 & 22 & 453 & \\
\hline EU375162.1.1248 & \begin{tabular}{|l} 
Uncultured Pseudomonas sp. clone Sc13 $16 \mathrm{~S}$ ribosomal \\
RNA gene, partial sequence
\end{tabular} & \begin{tabular}{|l} 
Bacterial communities from shoreline environments (costa da \\
morte, northwestern Spain) affected by the prestige oil spill
\end{tabular} & Coastal water & 114707 & gi:166407785]gb|EU375162.1] & 100 & 0 & 2 & 17 & \\
\hline EU531805.1.1258 & $\begin{array}{l}\text { Pseudomonas pseudoalcaligenes } 16 \mathrm{~S} \text { ribosomal RNA } \\
\text { gene partial sequence }\end{array}$ & \begin{tabular}{|l}
$\begin{array}{l}\text { Bacterial strains isolated from harvested tiger shrimp (Penneaus } \\
\text { Monodon) }\end{array}$ \\
\end{tabular} & Host-associated & 330 & 65/gb|EU531805.11 & 100 & 0 & 7 & 12 & \\
\hline EU536649.1.1395 & Uncultured bacterium clone nbt64e03 16 S ribosomal & A diversity profile of the human skin microbiota & Host-associated & 77133 & gil| & 100 & 0 & 5 & 503 & \\
\hline FJ005061.1.1494 & $\begin{array}{l}\text { Pseudomonas sp. enrichment culture clone Guo7 } 16 \mathrm{~S} \\
\text { ribosomal RNA gene, partial sequence }\end{array}$ & $\begin{array}{l}\text { The bioleaching feasibibitity for Pl/Zn smelting slag and } \\
\text { community characteristics of indigenous moderate- } \\
\text { thermophilic bacteria }\end{array}$ & Subsurface & 557865 & gi|204342383]|gb|FJ005061.1] & 100 & 0 & 7 & 17 & \\
\hline FJ170038.1.1503 & 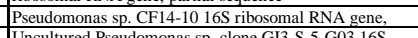 & $\begin{array}{l}\text { sediments of the South China Sea } \\
\text { Commen bons }\end{array}$ & Subsurface & 562724 & gi|206585088b|gb|FI170038.1| & 100 & 0 & 9 & 568 & \\
\hline FJ192249.1.1454 & $\begin{array}{l}\text { Uncultured Pseuddomonas sp. clone GI3-S-5-G03 16S } \\
\text { ribosomal NAA genen, partial sequence }\end{array}$ & $\begin{array}{l}\text { Comprehensive censusus of bacteriai i clean rooms by using } \\
\text { DNA microaray and cloning methods }\end{array}$ & Urban & 114707 & gi $209421869 \mathrm{gbl} \mid \mathrm{F} 192249.11$ & 100 & 0 & 26 & 712 & \\
\hline
\end{tabular}




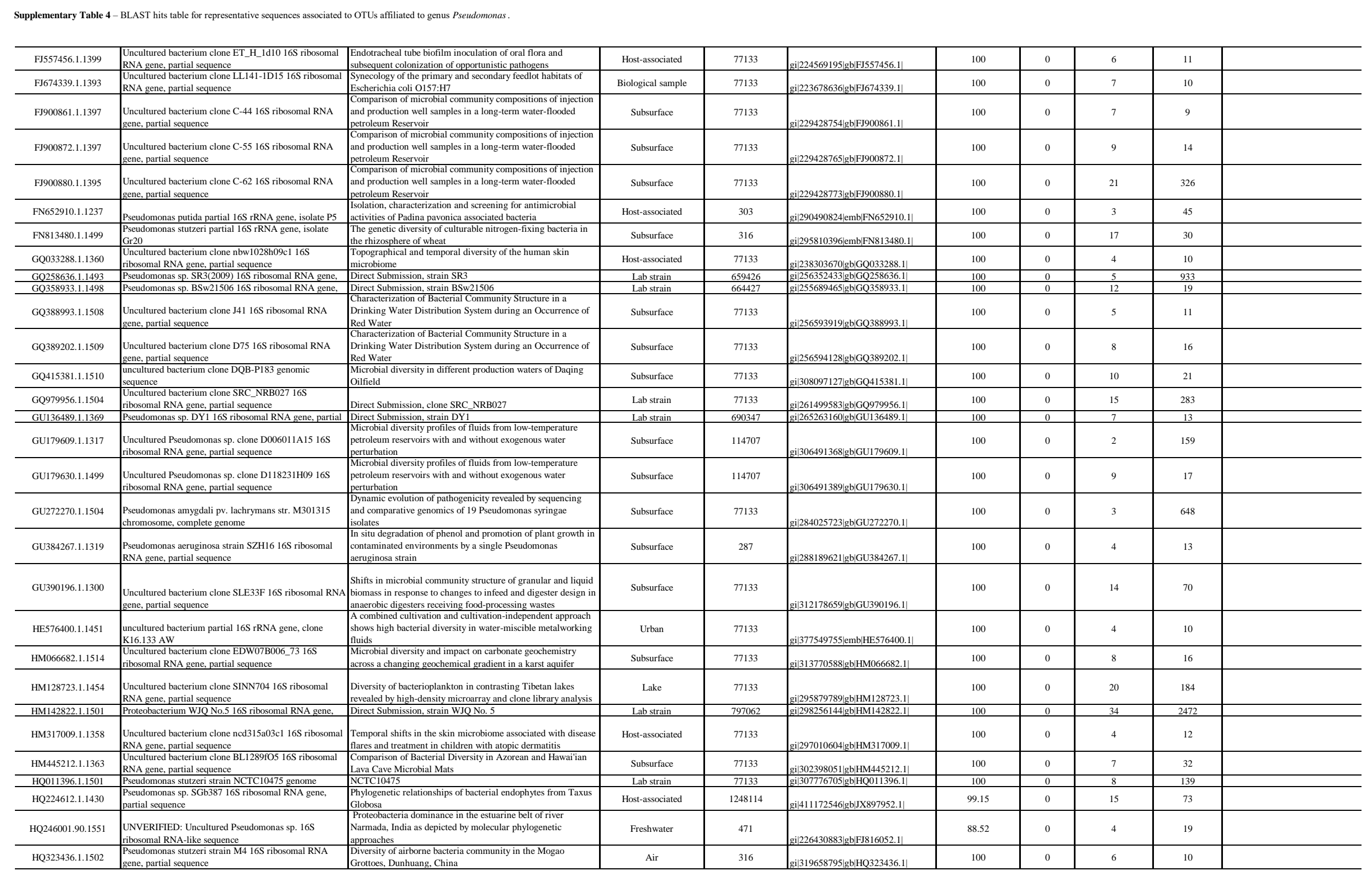




\begin{tabular}{|c|c|c|c|c|c|c|c|c|c|c|}
\hline HQ395163.1.1497 & $\begin{array}{l}\text { Uncultured bacterium clone OTUb51 } 16 \mathrm{~S} \text { ribosomal } \\
\text { RNA gene, partial sequence }\end{array}$ & $\begin{array}{l}\text { Culture-independent and culture-dependent methods reveal } \\
\text { diverse bacterial and archaeal communities in a biodegraded } \\
\text { Malaysian oil Reservooir }\end{array}$ & Subsurface & 77133 & gi|320172034|gb|HQ395163.1] & 100 & 0 & 4 & 18 & \\
\hline HQ438076.1.1492 & $\begin{array}{l}\text { Pseudomonas sp. TeU } 16 \text { S ribosomal RNA gene, partial } \\
\text { sequence }\end{array}$ & $\begin{array}{l}\text { Isolation and characterization of an environmental cadmium- } \\
\text { and tellurite-resistant Pseudomonas strain }\end{array}$ & Subsurface & 944290 & $\mathrm{gi}|318063761| \mathrm{gb} \mid \mathrm{HQ} 438076.1]$ & 100 & 0 & 8 & 11 & \\
\hline HQ848110.1.1406 & $\begin{array}{l}\text { Pseudomonas argentinensis strain PL-40-1 16S } \\
\text { ribosomal RNA gene, partial sequence }\end{array}$ & $\begin{array}{l}\text { Phylogenetic diversity of culturable bacteria isolated from the } \\
\text { disused ancient Kiyik River }\end{array}$ & Freshwater & 289370 & gi|340025389|gb|HQ848110.1| & 100 & 0 & 25 & 378 & \\
\hline JF430817.1.1403 & 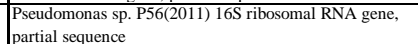 & \begin{tabular}{l|} 
Genetic and functional diversity of fluoressent Pseudomonas \\
from rhizospheric soils of wheat crop
\end{tabular} & Subsurface & 1079824 & gi| 345132366 |gb|JF430817.1| & 100 & 0 & 14 & 76 & \\
\hline JF500179.1.1495 & 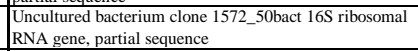 & $\begin{array}{l}\text { The deep biosphere in terrestrial sediments in the chesapeake } \\
\text { bay area, virginia, USA }\end{array}$ & Subsurface & 77133 & gi|343170179|gb|J5500179.1] & 100 & 0 & 11 & 230 & \\
\hline JF500197.1.1495 & 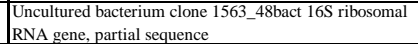 & $\begin{array}{l}\text { The deep biosphere in terrestrial sediments in the chesapaeake } \\
\text { bay area, virginia, USA }\end{array}$ & Subsurface & 77133 & gi|343170197|gb|JF500197.1] & 100 & 0 & 10 & 18 & \\
\hline JF741936.1.1498 & $\begin{array}{l}\text { Unsultured bacterium clone LHJB-8 } 16 \text { S ribosomal RNA } \\
\text { gene, partial sequence }\end{array}$ & Microbial communities in oil reservoirs with different salinities & Subsurface & 77133 & gi|332712701|gb|JF741936.1| & 100 & 0 & 3 & 10 & \\
\hline JF820098.1.1429 & $\begin{array}{l}\text { Pseuddomonas sp. PG-3-1 } 16 \text { S ribosomal RNA gene, } \\
\text { partial sequence }\end{array}$ & \begin{tabular}{|l|}
$\begin{array}{l}\text { Diversity of Culturable Butane-oxidizing Bacteria in Oil and } \\
\text { Gas Field Soil }\end{array}$ \\
\end{tabular} & Subsurface & 1036156 & gi|334690415|gb|JF20098.1] & 100 & 0 & 8 & 11 & \\
\hline JN609543.1.1229 & $\begin{array}{l}\text { Pseudomonas fluorescens strain Cantas14 } 165 \text { ribosomal } \\
\text { RNA gene, partial sequence }\end{array}$ & $\begin{array}{l}\text { The culturable intestinal microbiota of triploid and diploid } \\
\text { juvenile Atlantic salmon (Salmo salar) - a comparison of } \\
\text { composition and drug resistance }\end{array}$ & Host-associated & 294 & 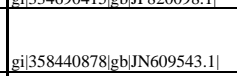 & 100 & 0 & 5 & 38 & \\
\hline JQ236848.1.1432 & 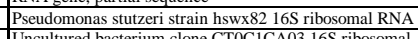 & 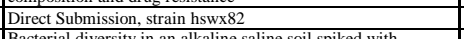 & Lab strain & 316 & 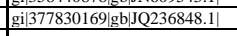 & 100 & 0 & 41 & 5419 & \\
\hline JQ425963.1.1492 & $\begin{array}{l}\text { Uncultured bacterium clone CTOCICA03 } 16 \text { ribosomal } \\
\text { RNA gene, partial sequence }\end{array}$ & $\begin{array}{l}\begin{array}{l}\text { aacterial diversity in an alkaline saline soil spiked with } \\
\text { Anthracene }\end{array} \\
\end{array}$ & Lake & 77133 & gi|385760667|gbJO425953.11 & 100 & 0 & 9 & 22 & \\
\hline JQ684327.1.1500 & $\begin{array}{l}\text { Uncultured bacterium clone HWGB-69 } 16 \text { S ribosomal } \\
\text { RNA gene partial secouence }\end{array}$ & $\begin{array}{l}\text { Bacterial and archaeal diversity in permafrost soil from Kunlun } \\
\text { Mountains Pasc. Tibet Plateaun of China }\end{array}$ & Subsurface & 77133 & (1) & 100 & 0 & 3 & 12 & \\
\hline JQ723717.1.1405 & 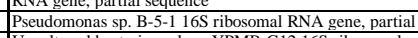 & beach sand in the west sea, Korea & Coastal water & 1172620 & 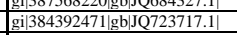 & 100 & 0 & 13 & 68 & \\
\hline JQ894900.1.1514 & \begin{tabular}{|l|} 
Uncultured bacterium clone YPMB-G12 $16 S$ ribosomal \\
RNA gene, partial sequence
\end{tabular} & $\begin{array}{l}\text { Microbial diversity of endosymbiont bacteria in the spiraling } \\
\text { Whitefly }\end{array}$ & Host-associated & 77133 & gi|411181008|gbJQQ894900.1] & 100 & 0 & 9 & 21 & \\
\hline JQ900532.1.1441 & \begin{tabular}{|l|}
$\begin{array}{l}\text { Pseudomonas mendocina strain B8 } 16 \text { S ribosomal RNA } \\
\text { gene, partial sequence }\end{array}$ \\
\end{tabular} & $\begin{array}{l}\text { Crude oil degrading bacterial isolates from ecological region of } \\
\text { Assam }\end{array}$ & Subsurface & 300 & gi|1022244732|gb|jQ900532.1] & 100 & 0 & 2 & 126 & \\
\hline JX222557.1.1395 & $\begin{array}{l}\text { Uncultured bacterium clone } \\
\text { EMIRGE__TT__s22b_12537 16S ribosomal RNA gene, }\end{array}$ & $\begin{array}{l}\text { Subsurface microbial community response to acetate } \\
\text { amendment }\end{array}$ & Subsurface & 77133 & $\mathrm{gi}|395559126 \mathrm{gb}| \mathrm{J} 222557.1]$ & 100 & 0 & 1 & 12 & \\
\hline JX222807.1.1498 & \begin{tabular}{|l|} 
Uncultured bacterium clone EMIRGE_OTU_3312d_3949 \\
16S ribosomal RNA gene, partial sequence
\end{tabular} & $\begin{array}{l}\text { Subsurface microbial community response to acetate } \\
\text { amendment }\end{array}$ & Subsurface & 77133 & gi|395559376|gb|XX222807.1] & 100 & 0 & 4 & 9 & \\
\hline JX223934.1.1501 & $\begin{array}{l}\text { Uncultured bacterium clone EMIRGE_OTU_s6ba__3133 } \\
\text { 16S ribosomal RNA gene, partial sequence }\end{array}$ & $\begin{array}{l}\text { Subsurface microbial community response to acetate } \\
\text { amendment }\end{array}$ & Subsurface & 77133 & $\mathrm{gi} \mid 395560503] \mathrm{gb} \mid \mathrm{J} 223934.1]$ & 100 & 0 & 5 & 10 & \\
\hline JX266364.1.1449 & $\begin{array}{l}\text { Pseudomonas sp. B2085 } 16 \text { S ribosomal RNA gene, } \\
\text { partial sequence }\end{array}$ & $\begin{array}{l}\text { Depth-Related Changes in Community Structure of Culturable } \\
\text { Mineral Weathering Bacteria and in Weathering Patterns } \\
\text { Caused by Them along Two Contrasting Soil Profiles }\end{array}$ & Subsurface & 1225045 & gi|402549839|gb|JX266364.1| & 100 & 0 & 31 & 558 & \\
\hline JX945764.1.1431 & $\begin{array}{l}\begin{array}{l}\text { Pseudomonas sp. LARP66 } 16 \text { S ribosomal RNA gene, } \\
\text { partial sequence }\end{array} \\
\end{array}$ & \begin{tabular}{|l} 
Microbial diversity of Ethiopian soda lakes assessed by \\
cultivation Methods
\end{tabular} & Lake & 1266816 & [gi|4282744238|gb|JX945764.1] & 100 & 0 & 8 & 11 & \\
\hline KC119131.1.1470 & Pseudomonas sp. RCC12 16 S ribosomal RNA gene, & 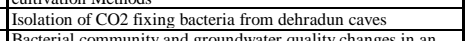 & Subsurface & 1268824 & 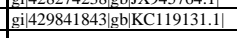 & 100 & 0 & 2 & 9 & \\
\hline KC166766.1.1460 & $\begin{array}{l}\text { Uncultured Pseudomonas sp. clone BC061 } 16 \mathrm{~S} \text { ribosomal } \\
\text { RNA gene, partial sequence }\end{array}$ & $\begin{array}{l}\text { Bacteriac communutity ynd groundwater quality changnges in an } \\
\text { anaerobic aquifer during groundwater recharge with aerobic } \\
\text { recycled water }\end{array}$ & Subsurface & 114707 & gi|5234538881|g||KC166766.1] & 100 & 0 & 5 & 15 & \\
\hline KC469080.1.1418 & 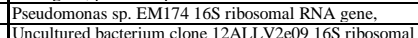 & 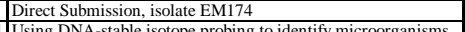 & Lab strain & 1282313 & givi452108584|gb|KC469080.1] & 100 & 0 & 6 & 19 & \\
\hline KC758944.1.1396 & $\begin{array}{l}\text { nncutfured bacterum conene } 2 \text { ALLV } 2009 \text { 16S ribosomal } \\
\text { RNA gene, partial sequence }\end{array}$ & 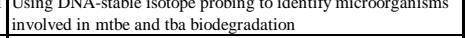 & Coastal water & 77133 & gi|478444906|gb|KC758944.1] & 100 & 0 & 2 & 22 & \\
\hline KC852955.1.1440 & $\begin{array}{l}\text { Pseudomonas cuatrocienegasensis strain LEH6_4A 16S } \\
\text { ribosomal RNA gene, partial sequence }\end{array}$ & $\begin{array}{l}\text { Midgut Microbial Community of Culex quinquefasciatus } \\
\text { Mosguito Populations from India }\end{array}$ & Host-associated & 77133 & gi| $223453428|\mathrm{gb}| K C 852955.1]$ & 100 & 0 & 25 & 293 & \\
\hline KF021824.1.1426 & Pseudomonas sp. H-144 16S ribosomal RNA gene, & Cultured diversity of marine bacteria & Seawater & 1345863 & 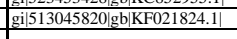 & 100 & 0 & 2 & 9 & \\
\hline KF494749.1.1502 & $\begin{array}{l}\text { Uncultured bacterium clone B24-205 } 165 \text { ribosomal } \\
\text { RNA gene, partial sequence }\end{array}$ & $\begin{array}{l}\text { Vertical changes of the structure of bacterial communities } \\
\text { through a permafrost core profile from Qinghai-Tibet Plateau }\end{array}$ & Subsurface & 77133 & gi|532529728|gb|KF494749.1] & 100 & 0 & 2 & 8 & \\
\hline KF494759.1.1501 & $\begin{array}{l}\text { Uncultured bacterium clone B9-456 16S ribosomal RNA } \\
\text { gene, partial sequence }\end{array}$ & $\begin{array}{l}\text { Vertical changes of the structure of bacterial communities } \\
\text { through a permafrost core profile from Qinghai-Tibet Plateau }\end{array}$ & Subsurface & 77133 & gi| $532529738|\mathrm{gb}| K F 494759.1]$ & 100 & 0 & 5 & 11 & \\
\hline KF657327.1.1480 & Pseudomonas mendocina strain 2E 16 S ribosomal RNA & \begin{tabular}{|l} 
Alkalo Tolerant Bacteria, water \\
\end{tabular} & Lake & 300 & 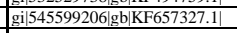 & 100 & 0 & 6 & 10 & \\
\hline KF722300.1.1267 & $\begin{array}{l}\text { Uncultured Pseudomonas sp. clone DVBSW_J342 } 16 S \\
\text { ribosomal RNA gene, partial sequence }\end{array}$ & $\begin{array}{l}\text { Response of bacterial community structure to seasonal } \\
\text { flfuctuation and anthropogenic pollution on coastal water of } \\
\text { Alang-Sosiya ship breaking yard, Bhavnagar, India }\end{array}$ & Coastal water & 114707 & gi|643039831|gb|KF722300.1] & 100 & 0 & 5 & 9 & \\
\hline KF836136.1.1422 & $\begin{array}{l}\text { Pseudomonas plecoglossicida strain SBADK2 16S } \\
\text { ribosomal RNA gene, partial sequence }\end{array}$ & rhizosphere bacteria for agricultural and environmental use & Subsurface & 70775 & gi|578003379|gb|KF836136.1] & 100 & 0 & 15 & 46 & \\
\hline KF851140.1.1502 & \begin{tabular}{|l} 
Uncultured Pseudomonas sp. clone BIP8S20-c24 16S \\
ribosomal RNA gene, partial sequence
\end{tabular} & \begin{tabular}{|l} 
Lithology-Controlled Bacteria Community in an Ammonium- \\
Rich Aquifer-Aquitard System in the Pearl River Delta, China
\end{tabular} & Subsurface & 114707 & [gi|582054428|gb|KF851140.1] & 100 & 0 & 10 & 30 & \\
\hline KF923425.1.1502 & Pseudomonas xanthomarina strain 1516 S ribosomal & 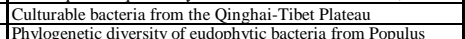 & Soil & 271420 & gi|i594591039|gb|KF923425.1] & 100 & 0 & 8 & 10 & \\
\hline KJ210658.1.1345 & $\begin{array}{l}\text { Pseudomonas xinjiangensis strain WL-257 } 16 \mathrm{~S} \\
\text { ribosomal RNA gene, partial sequence }\end{array}$ & 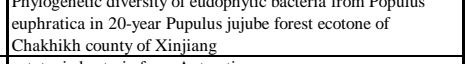 & Subsurface & 487184 & & 100 & 0 & 8 & 25 & \\
\hline KJ 424421.1 .1503 & |Pseudomonas sp. GW28-5 16S ribosomal RNA gene, & cytotoxic bacteria from Antarctica & Host-associated & 77133 & [gil601035987]|gb|KJ424421.1] & 100 & 0 & 4 & 121 & \\
\hline
\end{tabular}




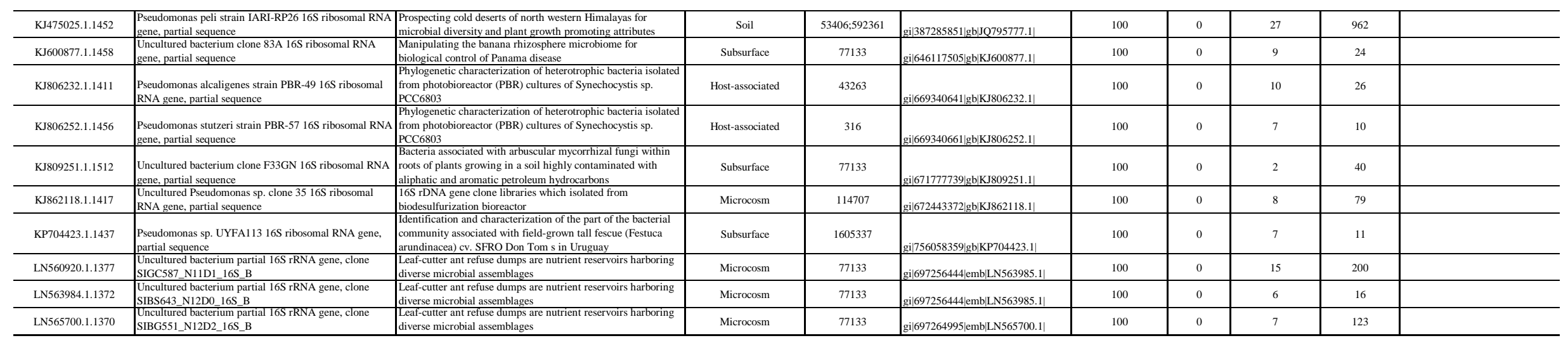




\section{References}

94 1. Borgonie, G. et al. Nematoda from the terrestrial deep subsurface of South Africa. Nature 474, 79-82 (2011).

2. McMahon, S. \& Parnell, J. Weighing the deep continental biosphere. FEMS Microbiol. Ecol. 87, 113-120 (2014).

3. Lau, M. C. Y. et al. Phylogeny and phylogeography of functional genes shared among seven terrestrial subsurface metagenomes reveal $\mathrm{N}$-cycling and microbial evolutionary relationships. Front. Microbiol. 5, 531 (2014).

5. Onstott, T. C. et al. Does aspartic acid racemization constrain the depth limit of the subsurface biosphere? Geobiology 12, 1-19 (2014).

6. McMurdie, P. J. \& Holmes, S. Phyloseq: An R Package for Reproducible Interactive Analysis and Graphics of Microbiome Census Data. PLoS One 8, e61217 (2013).

7. Kumar, S., Stecher, G. \& Tamura, K. MEGA7: Molecular Evolutionary Genetics Analysis Version 7.0 for Bigger Datasets. Mol. Biol. Evol. 33, 1870-1874 (2016).

8. Edgar, R. C. MUSCLE: multiple sequence alignment with high accuracy and high throughput. Nucleic Acids Res. 32, 1792-7 (2004).

9. Saitou, N. \& Nei, M. The neighbor-joining method: a new method for reconstructing phylogenetic trees. Mol. Biol. Evol. 4, 406-25 (1987).

10. Tamura, K., Nei, M. \& Kumar, S. Prospects for inferring very large phylogenies by using the

116 11. Barnhart, E. P. et al. Hydrogeochemistry and coal-associated bacterial populations from a 117 methanogenic coal bed. Int. J. Coal Geol. 162, 14-26 (2016).

118 12. Foght, J. et al. Culturable Bacteria in Subglacial Sediments and Ice from Two Southern Hemisphere Glaciers. Microb. Ecol. 47, 329-40 (2004).

13. Leuko, S. et al. Lysis efficiency of standard DNA extraction methods for Halococcus spp. in 